\title{
Discrimination in lending? Evidence from the Paycheck Protection Program
}

\author{
Rachel Atkins $\cdot$ Lisa Cook $\cdot$ Robert Seamans
}

Accepted: 21 June 2021 / Published online: 5 July 2021

(C) The Author(s), under exclusive licence to Springer Science+Business Media, LLC, part of Springer Nature 2021

\begin{abstract}
We assess the role of race in loans made through the Paycheck Protection Program (PPP). The PPP program, created by the U.S. government as a response to the Covid-19 pandemic, provides loans to small businesses so they can keep employees on their payroll. We argue that the historical record and PPP program design choices made it likely that many Black-owned businesses received smaller PPP loans than White-owned businesses. Using newly released data on the PPP program, we find that Black-owned businesses received loans that were approximately $50 \%$ lower than observationally similar White-owned businesses. The effect is marginally smaller in areas with more bank competition and disappeared over time as changes to the PPP program were implemented allowing for entry by fintechs and other nontraditional lenders.
\end{abstract}

Plain English Summary We find that Black-owned businesses received loans through the Paycheck Protection Program that were approximately 50 percent lower than White-owned businesses with similar characteristics. However, this difference in loan size shrank over time as more non-bank lenders such as fintechs were allowed to participate in the program

R. Atkins $\cdot$ R. Seamans $(\bowtie)$

NYU Stern School of Business, New York City, USA

e-mail: rcs10@stern.nyu.edu

L. Cook

Michigan State University and NBER, East Lansing, USA and began approving PPP loans. Loan size differences were also slightly smaller in zip codes containing a larger number of bank branches. These results are consistent with prior research which shows lending discrimination by commercial banks against Black borrowers. It is also consistent with studies showing that greater access to and competition among banks and other lenders can reduce discrimination. In light of these results we recommend that policy makers account for existing racial inequalities within banking or other systems in their program design to produce more equitable outcomes.

Keywords Minority-owned firms $\cdot$ Racial discrimination - Discrimination in financial markets . Overcoming discriminatory barriers

JEL Classifications $\quad \mathrm{G} 21 \cdot \mathrm{J} 16 \cdot \mathrm{L} 2 \cdot \mathrm{L} 26$

\section{Introduction}

The Covid-19 pandemic caused one of the sharpest economic downturns in U.S. history. Mandated and voluntary stay-at-home orders decimated revenues for small businesses, leaving them unable to meet their expenses and causing massive increases in temporary and permanent firm closures. The Paycheck Protection Program (PPP) was one of the many policy interventions by the U.S. government during the crisis. Between April 10, 2020 and August 8, 2020, PPP 
provided nearly 5.2 million loans through nearly 5500 lenders totaling $\$ 525$ billion for small businesses (500 employees or less) that could be used for operating expenses including payroll, mortgage interest or rent, utilities, and approved expenses. ${ }^{1}$ The program was administered using established financial institutions and initially relied heavily on commercial banks to distribute the funding.

Prior research provides much evidence of racial discrimination against Black-owned businesses by banks and other commercial lenders, raising concerns about whether Black-owned businesses would also face discrimination while seeking PPP funds. Early reports from media outlets and minority-owned business advocates highlighted the difficulties Black business owners faced when attempting to access PPP loans. Of surveyed Black business owners who sought assistance through the PPP, it is reported that $41 \%$ did not receive the funds and an additional $21 \%$ never heard back from lenders (Global Strategy Group, 2020). A New York Times report based on data from the Small Business Administration (SBA) and interviews with small businesses argues that a lack of connections with banks, together with some of the PPP's rules, contributed to this low level of access (Trevizo, 2020). However, Humphries et al. (2020) present data from the first round of PPP funding indicating that smaller businesses generally (not accounting for race) were less aware of the program, faced longer processing times, and were less likely to have their applications approved than larger businesses. They attribute this skewness to the "first-come, first-served" nature of the program design. Thus, it is unclear whether the reported difficulties that Black business owners faced while trying to access PPP funds was due to race or due to other factors such as firm size.

In this paper, we use newly released PPP loan data from the Small Business Administration (SBA) to investigate whether Black business owners were disproportionately underserved by the program. Our results indicate that Black-owned businesses received loan amounts that were approximately 50\% lower than observationally similar White-owned businesses. We also investigate whether differences in the number of banks in an area contributed to Black-White

\footnotetext{
1 https://www-sba-gov.proxy.library.nyu.edu/sites/default/files/ 2020-08/PPP_Report\%20-\%202,020-08-10-508.pdf.
}

differentials in loan amounts. Black-White differences in PPP loan amounts decrease in areas with more commercial bank branch locations, but this difference is not statistically significant. Thus, we find limited evidence consistent with Becker's (1957) theory that competition in commercial credit markets reduces taste-based discrimination. Finally, we study how changes to the PPP program affected Black-White differences in loan amounts. We find that over time the Black-White difference in loan amounts decreases, and this seems due in particular to a change in the PPP program that approved more non-bank lenders to participate in the program, including fintechs.

One challenge with the PPP loan data is that race is reported for only $10 \%$ of the loans. To address this challenge, we conduct our analyses on both the full set of loans and on the subset of loans for which race is reported. When working with the full set of loans, we treat "unanswered race" as the omitted category and compare loan sizes between Black and White business owners (both relative to the unanswered race category). When working with the subset of loans for which race is reported, we treat White business owner as the omitted category and consider how Black loan sizes compare to the omitted White category. We also include a Mills ratio derived from a first-stage Heckman selection approach to account for selection effects. The results are similar across both of these approaches.

Our analysis makes several contributions. To our knowledge, this is the first study to systematically examine whether there were differences in PPP loans to White- and Black-owned businesses or to investigate evidence of lending discrimination as a result of the PPP program. Black-owned businesses were among the hardest hit in the wake of the Covid-19 crisis; hence, this study offers insight into whether the federal government's primary intervention reached one of the most vulnerable groups of business owners. Estimates from the first few months of the crisis indicate that business activity fell $41 \%$ among Black-owned businesses, the largest drop of any racial sub-group (Fairlie, 2020). Nearly $20 \%$ of Black firm owners surveyed reported temporarily closing their businesses due to Covid-19 (Global Strategy Group, 2020). Though language in the CARES Act indicates that Congress explicitly intended for the PPP to prioritize businesses owned by "socially and economically disadvantaged individuals" (U.S. Congress, 2020), 
we show that the program fell short of meeting this stated goal with respect to Black-owned businesses.

We contribute to the nascent body of literature on the PPP program (Fairlie \& Fossen, 2021; Hubbard \& Strain, 2020; Humphries et al., 2020; Li, 2020; Shuai et al., 2020), small business outcomes during Covid 19 (Fairlie, 2020; Kalogiannidis, 2020; Ong et al. 2020), and government intervention during ongoing economic crises (Feyrer \& Sacerdote, 2011; Chodorow-Reich et al., 2012; Parker et al., 2013) by focusing on the challenges faced by Black business owners and by governments seeking to reach them during crises. Prior research on racial equity in the PPP program examined whether loans were allocated to communities based on the share of minority residents or businesses in a geographic location. Calem and Freedman (2020) find a positive relationship between a community's minority share of residents and receipt of PPP loans. Likewise, Fairlie and Fossen (2021) report that the relationship between the minority share of a community's residential or business population and PPP loan receipt was positive but small in magnitude. However, they show that loan size per employee had a negative relationship with minority share of the population. We build on these existing studies by conducting our analysis at the firm rather than community level.

We also contribute to literature on racial discrimination in small business lending (Bates \& Robb, 2013; Bates et al., 2018; Blanchard et al., 2008; Chen et al., 2021) by assessing whether government interventions in small business credit markets mirror or ameliorate discrimination and through what mechanisms. Our findings indicate that if governments utilize existing systems to enact policy or administer programs without accounting for the pre-existing inequities in those systems, then the enacted policies and programs will likely reproduce those same inequities. The SBA relied heavily on commercial banks to administer the PPP. As we describe below, these are institutions with a long history of racial discrimination, and Black-owned firms therefore had less access to PPP funds. When the SBA expanded the number and types of participating lenders, Blackowned businesses gained access to more funding through the PPP.

The remainder of this article proceeds as follows: Sect. 2 presents an overview of the PPP's history and features. Section 3 reviews literature on lending discrimination and access to bank financing and then presents hypotheses. In Sect. 4 we describe our data and analytical methods. We present results in Sect. 5 and Sect. 6 concludes with recommendations for policy and future research.

\section{The Paycheck Protection Program}

The Covid-19 pandemic caused one of the sharpest economic downturns in U.S. history. According to the Bureau of Economic Analysis (BEA), gross domestic product dropped by about $33 \%$ in the $2^{\text {nd }}$ quarter of 2020. ${ }^{2}$ Following guidelines from public health officials, state and local governments issued a variety of directives including stay-at-home orders, mandatory business closures, and social distancing requirements. Even in locations where governments did not mandate tight restrictions, residents often voluntarily followed public health guidance by social distancing, avoiding large gatherings, and working from home where possible. These mandated and voluntary actions decimated revenues for small businesses leaving them unable to meet their expenses causing massive increases in temporary and permanent firm closures (Fairlie, 2020). Chetty et al. (2020) show that much of the effects were driven by voluntary actions; state mandated re-openings had little effect on spending and employment. Many businesses were forced to furlough or lay off employees which led to massive increases in unemployment (Bartik et al., 2020).

The U.S. federal government created multiple policy interventions in response to the pandemic under the CARES Act, including the PPP. PPP was designed both to slow or stabilize the rate of small business closures and to reverse the rise in unemployment rates. In Round One of the PPP, Congress appropriated $\$ 349$ billion for small businesses in the form of loans that could be used for operating expenses including payroll, mortgage interest or rent, utilities, and approved expenses. They attempted to curb rising unemployment by offering to forgive PPP loans provided firms retain their employees or quickly rehire furloughed or previously laid-off workers. Moreover,

2 https://www.bea.gov/news/2020/gross-domestic-product2nd-quarter-2020-advance-estimate-and-annual-update. 
to reach a broad swath of workers through the PPP, Congress made loans widely available to employers including businesses, nonprofits, Tribal businesses, and veterans' organizations with 500 employees or less.

The program was administered by the Federal Small Business Administration (SBA). However, as always, SBA does not make loans to businesses directly and relies on SBA-qualified lenders which include depository institutions, such as banks and credit unions, as well as non-depository institution lenders, such as some Community Development Financial Institutions (CDFIs). Though loan recipients are not charged fees, SBA lenders can still charge fees associated with the loans which were paid by the federal government. SBA began accepting PPP loan applications on April 3, 2020. By April 16, 2020, funding had already run out. Congress acted by allocating an additional $\$ 310$ billion in funding for a second round of PPP loans. In Round Two, Congress made a few modifications, including allowing the smallest businesses and other businesses that were initially to be targeted to access program funding first.

The Federal Reserve created the Paycheck Protection Program Liquidity Facility (PPPLF) to give a financial boost to the PPP. The PPPLF provided credit to SBA lenders using PPP loans as collateral. In doing so, the Federal Reserve supplied added liquidity and thus expanded the capacity of financial institutions to make PPP loans. When announcing that the PPPLF was fully operational on April 16, 2020, the Federal Reserve had only made the facility available to depository institutions. By April $30^{\text {th }}$, it had extended access to all SBA-authorized lenders. This later action provided credit to smaller non-depository institutions that are more likely to lend in communities underserved by commercial banks, such as CDFIs and fintech operators (Liu \& Volker, 2020). Furthermore, these nontraditional lenders benefited disproportionately from the PPPLF's affordable credit thus bolstering the likelihood of their participation in the PPP.

Starting with the SBA Inspector General, many have highlighted the difficulties small business owners faced when attempting to access PPP funds (Global Strategy Group, 2020; Trevizo, 2020). ${ }^{3}$

\footnotetext{
${ }^{3}$ In contrast, others have highlighted that many organizations received loans that probably should not have, including Shake Shack, Harvard University and others (Jeschke, 2020).
}

Chetty et al. (2020) estimate that the PPP loans increased employment at small businesses by only about $2 \%$ (with an implied cost of $\$ 377,000$ per job saved). Reports speculate that since lenders were able to extract more in fees from larger businesses more quickly, they were dis-incentivized from granting loans requested by smaller businesses (Egan, 2020). Data from the Census Small Business Pulse Survey (SBPS) also identify challenges many small businesses faced when trying to access PPP loans. While $75 \%$ of small businesses applied for PPP loans, only $38 \%$ received them (Buffington et al., 2020). According to Biz2Credit, prior to the pandemic small business loan approval rates were about $28 \%$ at large banks and $50 \%$ at small banks. ${ }^{4}$ Furthermore, since the PPP was designed as a "first-come-first-served program" (Granja et al., 2020), small businesses may have been at a disadvantage given their lag time in knowledge about the program's eligibility requirements and benefits. Indeed, preliminary survey evidence reveals that smaller firms had less access to information about PPP and other programs when compared with large firms and that this information gap did not close much over time (Humphries et al., 2020).

Black-owned firms, which were already in a more fragile financial state relative to their White counterparts, were particularly hard hit by the Covid-19 crisis. This is partly due to Black-owned firms being more likely to operate in environments that produce poor business outcomes (McKinsey, 2020). Prior to the pandemic, 58\% of Black-owned businesses reported being at risk or financially distressed as compared with only $27 \%$ of White-owned firms (Mills \& Battisto, 2020). Black-owned firms are heavily concentrated in sectors most negatively affected by the pandemic - accommodation and food service, retail, and healthcare and social assistance. Fairlie (2020) reports findings from the April 2020 Current Population Survey that African American owned businesses experienced a $41 \%$ decline in owner activity. These firms were among those most in need of relief under the PPP.

\footnotetext{
${ }^{4}$ https://www.globenewswire.com/news-release/2020/04/07/ 2012911/0/en/Small-Business-Loan-Approval-Rates-Plumm eted-in-March-2020-Biz2Credit-Small-Business-LendingIndex.html.
} 
Yet, early evidence suggests that minority business owners faced unique challenges when attempting to access PPP loans (Flitter, 2020; Kurlyandchick, 2020). For example, of the 723 businesses in Salem MA that received PPP loans as of July 2020, only 7 identified as Black-owned (Leighton, 2020). One local preschool franchise owner explained that his existing relationship with a commercial bank allowed him to acquire PPP funding but that "many Black owners don't have relationships with banks." He also noted that "banks would choose to focus on their customers first" given the volume of loan requests brought on by Covid-19 and the PPP. Thus, one might predict disproportionately lower access to PPP loans for Black-owned firms given that loans originated primarily with commercial banks (at least initially), because these institutions traditionally underserve the Black community in at least two ways: (1) discrimination in lending decisions and (2) restricted access to bank branch locations. In the section that follows, we describe prior literature that provides more detail on these two ways, and then draw from this literature to derive formal hypotheses about differences in PPP loans for Black- and White-owned businesses.

\section{Prior literature and hypothesis development}

\subsection{Discrimination in lending}

Traditional commercial banks have a long history of racial discrimination (Blanchflower, et al., 2003; Blanchard et al., 2008; Hu et al., 2011; Bates \& Robb, 2013). As a result, Black and other non-White business owners enjoy less access to credit markets. Chatterji and Seamans (2012) attribute the finding that credit card deregulation had a positive effect on Black entrepreneurship to Black entrepreneurs having less access to capital from traditional sources such as banks, where they faced discrimination in lending. Their analysis shows greater post-deregulation rates of Black entrepreneurship in areas with higher levels of historical discrimination. Similarly, Atkins (2021) finds evidence that Black households are less able than Whites with similar amounts of home equity to access commercial credit to finance new ventures. Since home equity is a useful source of collateral lowering lender risk, it should reduce statistical discrimination. However, Atkins finds that increases in home equity were only associated with a higher probability of starting a business for White but not for Black households.

Literature on discrimination presents two primary types of discrimination: statistical and taste-based (Arrow, 1998; Fang \& Moro, 2010). When engaging in statistical discrimination, loan officers may use race as a proxy for unobserved characteristics that are correlated with both race and the probability of loan default. We do not expect PPP lenders to engage in statistical discrimination because the SBA guarantee on all PPP loans shifts $100 \%$ of the default risk from private banks to the federal government. Instead, we surmise that any observed discrimination is tastebased, stemming from either conscious or unconscious racial biases rather than being statistical in nature.

Banks discriminate against potential borrowers through at least four different mechanisms: loan application denial, discouraging borrowers, demanding a price premium, and supplying lower quantities of credit. Data from the 2014 Annual Survey of Entrepreneurs show that among loan applicants, 53\% of Black firm owners were denied loans as compared with only $24.7 \%$ of White firm owners. Studies using the Survey of Small Business Finance (SSBF) find that Black firm owners were twice as likely to be denied credit than their White counterparts (Blanchflower et al., 2003; Cavalluzzo \& Wolken, 2005). Fairlie et al., (2020) address critiques of analysis using these cross-sectional data sources by examining access to capital among startups in the longitudinal Kauffman Firm Survey. Controlling for both credit scores and net worth, they show that Black-owned ventures were three times less likely than Whites to report that their loan applications were always approved.

Fairlie et al., (2020) also estimate higher levels of discouraged borrowing among Black firm owners even among those deemed "creditworthy." Discouraged borrowers report not applying for credit for fear they will be turned down. Though Fairlie is not able to observe why discouraged borrowers believe they will be denied, accounts from audit studies illustrate how Black firm owners are treated differently by bank employees. Lederer et al. (2020) conducted an audit study of financial institutions in Washington DC between April 27 and May 29, 2020. They sent 63 matched pairs of Black and White testers to 32 bank branches and found that in $44 \%$ of tests where the 
testers requested PPP loans, White testers received more favorable treatment. Black testers were more likely to be discouraged from applying for a loan or were more likely to be steered towards a home equity line-of-credit product rather than SBA loan products made available by PPP.

In cases of taste-based discrimination, lenders may also operationalize discrimination by demanding a price premium for transactions with less desired clients. They can do so by charging higher interest rates on loans. Empirical results on interest rate differentials are mixed. Asiedu et al. (2012) use SSPF data from 1998 and 2003 to estimate racial differences in interest rates on approved loans. Controlling for owner and firm characteristics including credit history they find no differences in interest rates charged to Black firm owners when compared with Whites though they do find differences for Hispanic borrowers. Likewise, Blanchard et al. (2008) find no evidence of interest rate discrimination on bank loans though they do find that other lenders such as mutual fund and leasing companies exhibited discriminatory behavior against Black-owned businesses. On the contrary, Hu et al. (2011) use propensity score matching to estimate that Black business owners pay approximately 0.8 percentage point higher interest rates than corresponding White owners on average.

Bates and Robb (2013) find substantial differences in loan sizes awarded by race. Among firms with less than $\$ 500,000$ in sales, the gap in average loan size between minority and non-minority-owned firms was approximately $\$ 35,000$. Bates (1989), using data from the Characteristics of Business Owners survey, finds that firms located in minority neighborhoods were extended substantially smaller loans. Similarly, Fairlie et al., (2020), using data from the Kauffman Firm Survey, find persistent differences in the amount of bank loans offered to Black-owned businesses when compared with White-owned businesses.

To summarize, historical and contemporary evidence reveals lending discrimination against Black firm owners by commercial banks. Though there is mixed evidence on interest rate discrimination, banks consistently deny credit to Black-owned firms more frequently, discourage them from borrowing more often, and offer them smaller loan amounts than their White counterparts. Thus, given the SBA's heavy reliance on these institutions to administer the PPP, we predict that lending discrimination will reduce access to PPP loans for Black-owned firms. Since the federal government assumes $100 \%$ of the default risk associated with PPP loans, we argue that any observed discrimination is more likely to stem from racial bias rather than statistical correlations. We formally state this idea in the following hypothesis:

H1: Black-owned businesses access less PPP loan funds than White-owned businesses, all else equal.

\subsection{Role of banks}

In addition to discrimination, banks have historically provided Black business owners with less access to commercial credit through location decisions. Proximity to bank branch locations increases access to commercial credit and prior literature suggests that traditional banks choose to locate branches in fewer minority neighborhoods than White neighborhoods. For example, several studies find negative correlations between the proportion of minority residences and the probability of a commercial bank branch location (Wheatly, 2010; Cover, 2011; Hegerty, 2020). In a comparative case study, Hegerty (2016) considers Milwaukee and Buffalo in search of banking "deserts." He finds that block groups with fewer banks are more likely to occur in areas with fewer White residents. Kashian et al. (2018) examined the growth of bank deserts during the Great Recession period. African Americans living in inner cities were more likely to live in bank deserts and saw that probability increase over the course of the recession.

Proximity to branch locations increase access to loans through at least two mechanisms. First, potential borrowers are able to establish relationships with lenders through more frequent interactions to nearby branches. Lack of access to bank branches thus hinders Black business owners from establishing relationships with lenders. Historically, Black households are less likely to have a bank account as compared with White households. According to the Survey of Consumer Finances, the percent of unbanked Black and Hispanic households has decreased over time, but still greatly outpaces the percent of unbanked White households. A report by the Council of Economic Advisers (2016) reports that while the White-Nonwhite gap has decreased from about 30 percentage 
points in 1989, it was still about 10 percentage points as of 2013.

In addition, lack of proximity to bank branches can hinder Black business owners from developing vital relationships with lenders. Through relationship lending, banks collect information about firms, their owners and their communities that they use to assess risk and structure credit terms accordingly (Berger \& Udell, 2002). These relationships help address information asymmetries and potentially increase credit availability. Banks are able to collect this soft information on firms at a lower cost when borrowers are close by (Elyasiani \& Goldberg, 2004). Without an established relationship to a commercial bank many Black households and Black business owners struggle to acquire credit from these lenders for business startups or other purposes.

Furthermore, early studies of the PPP program indicate that such relationships were vital to securing the funds (Cororaton, \& Rosen, 2020). Li and Strahan (2020) conclude that PPP lending reflects characteristics of relationship lending including prior experience with the lender. Though the program poses none of the default risks that relationships are intended to shield banks from, $\mathrm{Li}$ and Strahan surmise that banks may be using the program to ensure that their borrowers survive the crisis. Additionally, the existing relationships lower the cost of the transaction. Amiram and Rabetti (2020) show that borrowers benefitted from relationship lending when applying for PPP loans. Firms with existing lending relationships received larger PPP loan amounts and faster approvals.

A second mechanism through which bank branch locations facilitate lending is increased credit market competition. Areas with more bank branches are associated with more credit market competition and less concentration (Cavalluzzo \& Cavalluzzo, 1998). In areas with fewer bank branches, lenders have greater market power and are able to act on racial preferences when rationing credit without sacrificing revenue. Cavalluzzo et al. (2002) evaluate racial differences in several lending outcomes controlling for a rich set of borrower characteristics. They find evidence that White male business owners fared better than their Black counterparts but that outcome gaps narrowed in more competitive geographic credit markets. The authors point to Becker's theory (1957) which posits that taste-based discrimination is costly and should invite entry to secure uncaptured profits. While Ferguson and Peters (2000) explain that discrimination may persist indefinitely even in competitive markets when discrimination is not costly to the lender, Michell and Pearce (2011) provide some evidence that the types of lenders that enter a market can influence the extent to which competition drives down discrimination.

In summary, proximity to bank locations increases access to commercial credit. Proximity increases access by more readily facilitating banking relationships and by increasing credit market competition. Since banks locate near Black-owned firms less often, Black business owners have fewer opportunities to establish banking relationships and therefore enjoy less access to commercial credit. Early reporting suggested that banks had incentives to prioritize borrowers with whom they had existing relationships when making PPP loans. Thus, we predict that the disproportionately low access to PPP loans among Blackowned businesses will be most evident in neighborhoods with fewer bank branches. We formally state this idea in the following hypothesis:

H2: The effect in $\mathrm{H} 1$ is stronger in areas with fewer bank branches.

\subsection{Role of non-traditional lenders}

Since many Black firm owners lack access to bank branches and bank credit, Black-owned firms may rely on non-traditional lenders such as fintech firms, CDFIs, or other nonprofits for business loans more often than White firm owners (Erel \& Liebersohn, 2020). CDFIs typically raise capital via grants or low interest loans from government entities, foundations, banks seeking to fulfill Community Reinvestment Act (CRA) requirements, individual donors, and religious institutions (Benjamin, 2004). da Motta (2020) estimates that Black-owned businesses had 1.7 times greater odds of applying for funding from a CDFI than White-owned firms.

Mitchell and Pearce (2020) explain that non-bank lenders often have fewer incentives to engage in statistical discrimination than banks. One reason is that these institutions are often better able to repossess and redeploy loan collateral in the event of default due to complementary business lines. Indeed, 


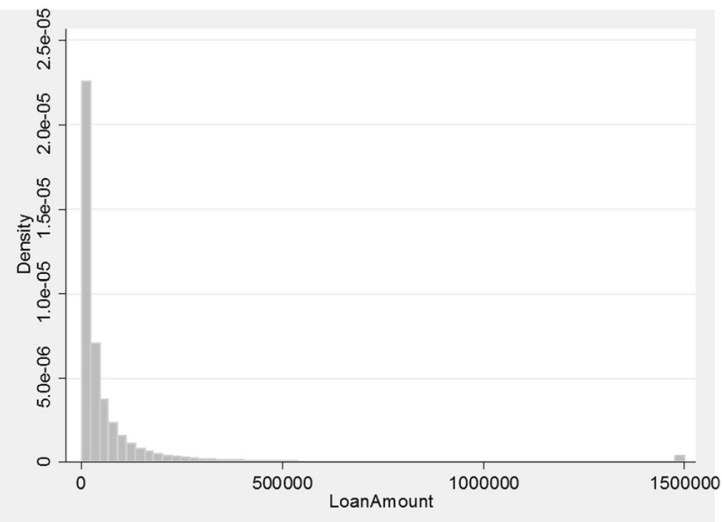

Fig. 1 Histogram of loan amounts (\$)

Mitchell and Pearce analyze data from the National Survey of Small Business Finance and find that nonbanks gave equal treatment to minority and nonminority borrowers seeking non- line-of-credit loans while banks tended to deny loans to minority borrowers more often than White borrowers. Furthermore, many non-profit lenders such as community development financial institutions were explicitly created to meet the funding needs of underserved communities.

Having a variety of lender types may increase the supply of credit in a given market and increase access to credit for Black-owned firms. Carey et al. (1998) find that while banks were just as likely as financing companies to offer credit to low information firms, financing companies were willing to take on the riskier borrowers by comparison. Daniels and Ramirez (2008) also examine lender specialization and find that non-bank lenders are more willing to generate loans to less transparent firms. Evidence from the UK reiterates the role of non-bank lenders in increasing credit supply for minority business owners. Smallbone et al., (2003) find that ethnic minority businesses were more likely than White-owned business to utilize non-bank lenders having experienced higher rates of denial from traditional bank lenders.

Non-traditional lenders appear to have played a role in delivering PPP loans to Black-owned businesses as well. According to a 2020 article in Fortune, "black businesses had more success obtaining funds in the second round of PPP relief, in part

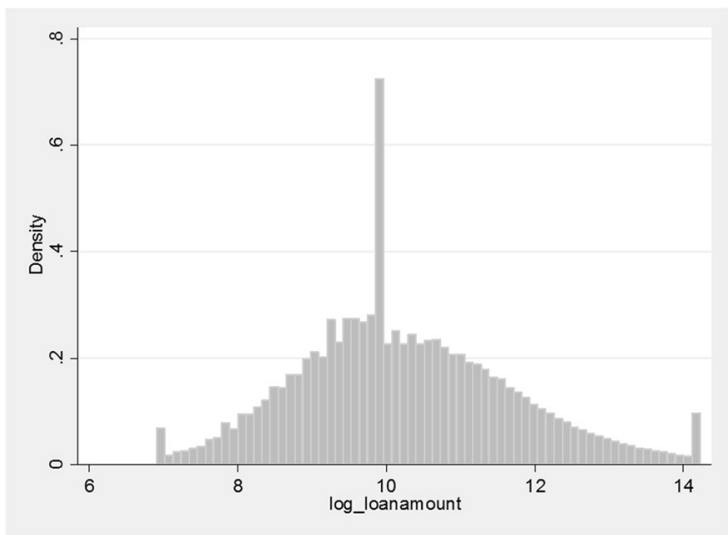

Fig. 2 Histogram of Ln loan amounts (\$)

through working with local banks and fintech companies like Kabbage and Square." ${ }^{, 5}$ Indeed, Howell et al. (2020) examine which institutions supplied PPP loans to businesses by race of the owner. They report that fintechs, minority development institutions, and nonprofits accounted for the largest share of PPP loans to Black-owned firms by far. Combined CDFI and MDIs accounted for just $4.3 \%$ of the total number of loans and fintech accounted for $4.8 \%$ of the total as of August 2020 (SBA, 2020). Most of these non-bank institutions were not approved to participate in the program until the second round of PPP funding was authorized.

Thus, since non-traditional lenders provided most of the loans to Black-owned firms and non-traditional lenders were approved to participate after April $30^{\text {th }}$, we predict that access to PPP funds likely increased for Black-owned businesses in round 2 of funding after April $30^{\text {th }}$. In turn, this likely led to a decrease in effects we hypothesize for H1. We formally state this idea in the following hypothesis:

H3: The effect of $\mathrm{H} 1$ decreases after April 30, 2020

\footnotetext{
5 https://fortune.com/2020/06/12/black-owned-business-coron avirus-sean-diddy-combs-enterprises-tarik-brooks/.
} 
Table 1 Summary statistics

\begin{tabular}{|c|c|c|c|c|c|c|c|c|}
\hline \multirow[b]{2}{*}{ Variable } & \multicolumn{4}{|c|}{ A: Full sample $(N \sim 4.5 \mathrm{M})$} & \multicolumn{4}{|c|}{ B: Sub-sample for race answered $(N \sim 500 \mathrm{~K})$} \\
\hline & Mean & St. dev & Min & Max & Mean & St. dev & Min & $\operatorname{Max}$ \\
\hline Loan amount & 89,498 & 206,692 & 1000 & $1,500,000$ & 112,761 & 223,691 & 1000 & $1,500,000$ \\
\hline Ln loan amount & 10.252 & 1.438 & 6.908 & 14.221 & 10.579 & 1.445 & 6.908 & 14.221 \\
\hline Jobs reported & 10.622 & 30.925 & 0.000 & 500.000 & 14.219 & 32.798 & 0.000 & 500.000 \\
\hline Asian owner & 0.012 & 0.107 & 0.000 & 1.000 & 0.112 & 0.316 & 0.000 & 1.000 \\
\hline Black owner & 0.003 & 0.058 & 0.000 & 1.000 & 0.032 & 0.176 & 0.000 & 1.000 \\
\hline Hispanic owner & 0.008 & 0.090 & 0.000 & 1.000 & 0.078 & 0.269 & 0.000 & 1.000 \\
\hline White owner & 0.080 & 0.271 & 0.000 & 1.000 & 0.771 & 0.420 & 0.000 & 1.000 \\
\hline Other race owner & 0.000 & 0.006 & 0.000 & 1.000 & 0.000 & 0.018 & 0.000 & 1.000 \\
\hline Unanswered race owner & 0.896 & 0.305 & 0.000 & 1.000 & & & & \\
\hline Veteran & 0.007 & 0.081 & 0.000 & 1.000 & 0.032 & 0.176 & 0.000 & 1.000 \\
\hline Female owner & 0.049 & 0.216 & 0.000 & 1.000 & 0.233 & 0.423 & 0.000 & 1.000 \\
\hline Corporation & 0.293 & 0.455 & 0.000 & 1.000 & 0.339 & 0.473 & 0.000 & 1.000 \\
\hline Non-profit & 0.035 & 0.183 & 0.000 & 1.000 & 0.019 & 0.137 & 0.000 & 1.000 \\
\hline LLC or LLP & 0.283 & 0.450 & 0.000 & 1.000 & 0.310 & 0.463 & 0.000 & 1.000 \\
\hline Median income (zip code) & 5445 & 4309 & 751 & 210,964 & 5341 & 3963 & 751 & 123,591 \\
\hline \% Bachelors (zip code) & 0.227 & 0.096 & 0.000 & 1.000 & 0.206 & 0.093 & 0.000 & 1.000 \\
\hline \% Rural (zip code) & 0.136 & 0.255 & 0.000 & 1.000 & 0.222 & 0.318 & 0.000 & 1.000 \\
\hline
\end{tabular}

\section{Data and methods}

\subsection{Data}

We test our hypotheses using several sources of data. Data on individual PPP loans comes from the U.S. Treasury. ${ }^{6}$ The PPP loan-level data provides us with information about the size of the loan, which is the main dependent variable in most of our regressions. We use this dependent variable to study how race affects loan size. We use differences in race to study the role of discrimination. Since the PPP program sets interest at $1 \%$ for all loans, the price mechanism for rationing this credit is unavailable to banks; thus, we would not expect to observe interest rate discrimination. We do not measure discrimination using loan denial rates since SBA does not provide data on loan applications. The data does not capture the ways potential borrowers are treated by loan officers hence we are unable to measure discrimination in borrower discouragement.

Loan amounts are highly skewed (see Figs. 1, 2 and Tables 1, 2, 3, 4, 5, 6, and 7). In addition, some

\footnotetext{
${ }^{6}$ https://home.treasury.gov/policy-issues/cares-act/assistancefor-small-businesses/sba-paycheck-protection-program-loanlevel-data.
}

of the loan amounts appear to have been recorded incorrectly with values such as " 0 " or " 1 ." To address these issues, we winsorize the loan amounts (any loan less than $\$ 1000$ is coded as $\$ 1000$ and any loan more than $\$ 1.5$ million is coded at $\$ 1.5$ million) and take the natural $\log$ of the loan amount. (In Appendix Table 8, we present a set of results without winsorizing; the results are almost identical.) The PPP data also provides us with information about the number of jobs that the loan supports, the race of the owner (if reported), the gender of the owner (if reported) and the veteran status of the owner (if reported). Data about bank branches comes from the FDIC. ${ }^{7} \mathrm{We}$ aggregate the bank branch data to the zip code level to match to the PPP loan data. We use the FDIC data to create a count of the number of bank branches in the county. Demographic data at the zip code level comes from the U.S. Census Bureau.

Summary statistics of the variables are reported in Table 1. Panel A reports data from the full sample. There are approximately 4.5 million loans in the full sample. The average loan was about $\$ 90,000$. Most loan recipients did not report race (unanswered race

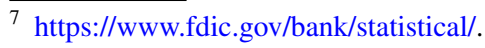


Table 2 Prediction of unanswered race

(1)

Dependent variable: race unanswered

$\%$ Black population (zip code)

$\%$ Hispanic population (zip code)

$\%$ Native American population (zip code)

$\%$ Other race population (zip code)

Median Income (zip code)

$\%$ Bachelors (zip code)

$\%$ Rural (zip code)

Jobs reported

Loan amount

Veteran

Female owner

Corporate form dummies

2-Digit NAICS Dummies

State dummies

Observations

Log likelihood
$\%$ Asian population (zip code)

$0.231 * * *$

$\begin{array}{lllll} & {[0.000]} & {[0.000]} & {[0.000]} & {[0.000]} \\ -0.000^{* * *} & -0.000^{* * *} & -0.000^{* * *} & \\ {[0.000]} & {[0.000]} & {[0.000]} & \\ -1.226^{* * *} & -1.235^{* * *} & -1.237 * * * & -1.237 * * * \\ & {[0.007]} & {[0.007]} & {[0.007]} & {[0.007]} \\ -1.325^{* * *} & -1.337^{* * *} & -1.303^{* * *} & -1.303 * * * \\ & {[0.003]} & {[0.003]} & {[0.003]} & {[0.003]} \\ & \text { Yes } & \text { Yes } & \text { Yes } & \text { Yes } \\ & & \text { Yes } & \text { Yes } & \text { Yes } \\ & & & \text { Yes } & \text { Yes } \\ & 4,833,101 & 4,403,731 & 4,403,709 & 4,403,709\end{array}$

Standard errors in brackets

${ }^{* * *} p<0.01,{ }^{* *} p<0.05,{ }^{*} p<0.1$

Table 3 PPP national-level statistics

\begin{tabular}{llllllll}
\hline Race/ethnicity & Number & Percent & Total loans (\$) & Total emp & Loan (\$) per org & Emp per Org & Loan per emp \\
\hline $\begin{array}{l}\text { American Indian or Alaska } \\
\quad \text { Native }\end{array}$ & 2794 & 0.06 & $391,000,000$ & 41,204 & 139,943 & 14.75 & 9489 \\
Asian & 58,274 & 1.17 & $5,320,000,000$ & 726,329 & 91,293 & 12.46 & 7325 \\
Black or African American & 16,453 & 0.33 & $1,360,000,000$ & 177,989 & 82,660 & 10.82 & 7641 \\
Hispanic & 41,171 & 0.83 & $4,230,000,000$ & 546,148 & 102,742 & 13.27 & 7745 \\
Unanswered & $4,450,201$ & 89.44 & $421,000,000,000$ & $40,000,000$ & 94,602 & 8.99 & 10,525 \\
White & 406,663 & 8.17 & $53,400,000,000$ & $5,600,000$ & 131,313 & 13.77 & 9536 \\
\hline
\end{tabular}

(2)

[0.011]

[0.010]

$0.476 * * *$

[0.006]

$0.447 * * *$

[0.005]

$-0.327 * * *$

[0.035]

$0.802 * * *$

[0.024]

$0.000 * * *$

[0.000]

$1.127 * * *$

[0.011]

$-0.341 * * *$

[0.004]

\section{(3)}

(4)

(5)

$0.422 * * *$

$0.221 * * *$

$-0.067 * * *$

$-0.067 * * *$

[0.011]

[0.013]

[0.013]

$0.417 * * *$

$0.292 * * *$

$0.248 * * *$

[0.006]

[0.006]

[0.007]

[0.007]

$0.437 * * *$

$0.432 * * *$

$0.151 * * *$

$0.148 * * *$

[0.005]

[0.005]

[0.007]

[0.007]

$-0.248 * * *$

$-0.197 * * *$

$0.311 * * *$

$0.309 * * *$

[0.038]

[0.038]

[0.044]

[0.044]

$0.921 * * *$

$0.940 * * *$

$0.813 * * *$

$0.793 * * *$

[0.026]

[0.026]

$0.000 * * *$

[0.035]

[0.035]

$0.000 * * *$

[0.000]

$1.156^{* * *}$

$1.017 * * *$

$0.000 * * *$

$0.000 * * *$

[0.000]

[0.000]

$0.883 * * *$

$0.872 * * *$

[0.012]

[0.012]

[0.013]

[0.013]

$-0.362 * * *$

$-0.299 * * *$

$-0.183 * * *$

$-0.173 * * *$

[0.004]

[0.004]

[0.004]

[0.004]

$-0.002 * * *$

[0.000]

$-0.000 * * *$

[0.000]

$-0.000^{* * *}$

$-0.000^{* * *}$

$-0.000^{* * *}$

$-1.226^{* * *}$

$-1.235^{* * *}$

[0.007]

$-1.303 * * *$

[0.003

Yes

Yes

$4,833,10$

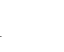

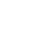


Table 4 Top lenders by type, over time

\begin{tabular}{lllll}
\hline Panel A & & & & \\
\hline & Loans prior to April 30 & & Loans after April 30 & \\
& Number & Percent & Number & Percent \\
Top 5 bank & 652,138 & $19 \%$ & 265,335 & $19 \%$ \\
Top 5 alternative & 177,869 & $5 \%$ & 437,808 & $32 \%$ \\
Panel B & & & & \\
& Loans prior to April 30 & & Loans after April 30 & \\
& White & Black & White & Black \\
Top 5 bank & 1934 & 72 & 2803 & 298 \\
Top 5 alternative & 444 & 30 & 2525 & 636 \\
\hline
\end{tabular}

Table 5 PPP loan-level results

\begin{tabular}{|c|c|c|c|c|c|c|}
\hline & (1) & (2) & (3) & (4) & (5) & (6) \\
\hline \multicolumn{7}{|c|}{ Dependent variable: Ln loan amount } \\
\hline Asian owner & $\begin{array}{l}0.247 * * * \\
{[0.006]}\end{array}$ & $\begin{array}{l}0.234 * * * \\
{[0.006]}\end{array}$ & $\begin{array}{l}0.074 * * * \\
{[0.005]}\end{array}$ & $\begin{array}{l}0.044 * * * \\
{[0.005]}\end{array}$ & $\begin{array}{l}0.028 * * * \\
{[0.005]}\end{array}$ & $\begin{array}{l}0.022 * * * \\
{[0.005]}\end{array}$ \\
\hline Black owner (H1) & $\begin{array}{l}-0.144 * * * \\
{[0.011]}\end{array}$ & $\begin{array}{l}-0.138 * * * \\
{[0.011]}\end{array}$ & $\begin{array}{l}-0.158 * * * \\
{[0.010]}\end{array}$ & $\begin{array}{l}-0.140 * * * \\
{[0.010]}\end{array}$ & $\begin{array}{l}-0.137 * * * \\
{[0.009]}\end{array}$ & $\begin{array}{l}-0.162 * * * \\
{[0.009]}\end{array}$ \\
\hline Hispanic owner & $\begin{array}{l}0.152 * * * \\
{[0.007]}\end{array}$ & $\begin{array}{l}0.151 * * * \\
{[0.007]}\end{array}$ & $\begin{array}{l}0.080 * * * \\
{[0.006]}\end{array}$ & $\begin{array}{l}0.050 * * * \\
{[0.006]}\end{array}$ & $\begin{array}{l}0.106 * * * \\
{[0.006]}\end{array}$ & $\begin{array}{l}0.089 * * * \\
{[0.006]}\end{array}$ \\
\hline White owner & $\begin{array}{l}0.424 * * * \\
{[0.002]}\end{array}$ & $\begin{array}{l}0.496 * * * \\
{[0.002]}\end{array}$ & $\begin{array}{l}0.363 * * * \\
{[0.002]}\end{array}$ & $\begin{array}{l}0.334 * * * \\
{[0.002]}\end{array}$ & $\begin{array}{l}0.349 * * * \\
{[0.002]}\end{array}$ & $\begin{array}{l}0.357 * * * \\
{[0.002]}\end{array}$ \\
\hline Other race owner & $\begin{array}{l}-1.113^{* * * *} \\
{[0.114]}\end{array}$ & $\begin{array}{l}-1.113^{* * *} \\
{[0.116]}\end{array}$ & $\begin{array}{l}-0.752 * * * \\
{[0.100]}\end{array}$ & $\begin{array}{l}-0.828 * * * \\
{[0.098]}\end{array}$ & $\begin{array}{l}-0.281 * * * \\
{[0.098]}\end{array}$ & $\begin{array}{l}-0.298 * * * \\
{[0.098]}\end{array}$ \\
\hline Median income (zip code) & & $\begin{array}{l}0.000 * * * \\
{[0.000]}\end{array}$ & $\begin{array}{l}0.000 * * * \\
{[0.000]}\end{array}$ & $\begin{array}{l}0.000 * * * \\
{[0.000]}\end{array}$ & $\begin{array}{l}0.000 * * * \\
{[0.000]}\end{array}$ & $\begin{array}{l}0.000 * * * \\
{[0.000]}\end{array}$ \\
\hline \% Bachelors (zip code) & & $\begin{array}{l}0.214 * * * \\
{[0.008]}\end{array}$ & $\begin{array}{l}0.348 * * * \\
{[0.007]}\end{array}$ & $\begin{array}{l}0.404 * * * \\
{[0.007]}\end{array}$ & $\begin{array}{l}0.333 * * * \\
{[0.007]}\end{array}$ & $\begin{array}{l}0.159 * * * \\
{[0.008]}\end{array}$ \\
\hline \% Rural (zip code) & & $\begin{array}{l}-0.493 * * * \\
{[0.003]}\end{array}$ & $\begin{array}{l}-0.313 * * * \\
{[0.003]}\end{array}$ & $\begin{array}{l}-0.320 * * * \\
{[0.003]}\end{array}$ & $\begin{array}{l}-0.310 * * * \\
{[0.003]}\end{array}$ & $\begin{array}{l}-0.213^{* * *} \\
{[0.003]}\end{array}$ \\
\hline Jobs reported & & & $\begin{array}{l}0.022 * * * \\
{[0.000]}\end{array}$ & $\begin{array}{l}0.021 * * * \\
{[0.000]}\end{array}$ & $\begin{array}{l}0.021 * * * \\
{[0.000]}\end{array}$ & $\begin{array}{l}0.022 * * * \\
{[0.000]}\end{array}$ \\
\hline Veteran & & & $\begin{array}{l}0.294 * * * \\
{[0.007]}\end{array}$ & $\begin{array}{l}0.268 * * * \\
{[0.007]}\end{array}$ & $\begin{array}{l}0.256 * * * \\
{[0.007]}\end{array}$ & $\begin{array}{l}0.895 * * * \\
{[0.011]}\end{array}$ \\
\hline Female owner & & & $\begin{array}{l}-0.123 * * * \\
{[0.003]}\end{array}$ & $\begin{array}{l}-0.103 * * * \\
{[0.003]}\end{array}$ & $\begin{array}{l}-0.098 * * * \\
{[0.003]}\end{array}$ & $\begin{array}{l}0.549 * * * \\
{[0.009]}\end{array}$ \\
\hline Mills ratio & & & & & & $\begin{array}{l}-1.079 * * * \\
{[0.015]}\end{array}$ \\
\hline Corporate form dummies & & & Yes & Yes & Yes & Yes \\
\hline 2-Digit NAICS dummies & & & & Yes & Yes & Yes \\
\hline State dummies & & & & & Yes & Yes \\
\hline Observations & $4,855,505$ & $4,833,101$ & $4,516,504$ & $4,403,731$ & $4,403,711$ & $4,403,709$ \\
\hline R-squared & 0.007 & 0.016 & 0.298 & 0.333 & 0.340 & 0.341 \\
\hline
\end{tabular}

Standard errors in brackets

**** $p<0.01,{ }^{* *} p<0.05, \stackrel{*}{p}<0.1$ 
Table 6 PPP loan results split by number of bank branches
Standard errors in brackets

${ }^{* * *} p<0.01,{ }^{* *} p<0.05$, ${ }^{*} p<0.1$

\begin{tabular}{|c|c|c|c|c|}
\hline & (1) & $(2)$ & (3) & (4) \\
\hline \multicolumn{5}{|c|}{ Dependent variable: Ln loan amount } \\
\hline Number of branches & $1-3$ & $4-6$ & $7-9$ & $10+$ \\
\hline Asian owner & $\begin{array}{c}-0.012 \\
{[0.015]}\end{array}$ & $\begin{array}{l}0.022^{*} \\
{[0.013]}\end{array}$ & $\begin{array}{l}0.055 * * * \\
{[0.015]}\end{array}$ & $\begin{array}{l}0.023 * * \\
{[0.011]}\end{array}$ \\
\hline Black owner (H2) & $\begin{array}{l}-0.241 * * * \\
{[0.021]}\end{array}$ & $\begin{array}{l}-0.143 * * * \\
{[0.022]}\end{array}$ & $\begin{array}{l}-0.143 * * * \\
{[0.026]}\end{array}$ & $\begin{array}{l}-0.104 * * * \\
{[0.020]}\end{array}$ \\
\hline Hispanic owner & $\begin{array}{l}0.028 \\
{[0.017]}\end{array}$ & $\begin{array}{l}0.095 * * * \\
{[0.018]}\end{array}$ & $\begin{array}{l}0.085 * * * \\
{[0.021]}\end{array}$ & $\begin{array}{l}0.116^{* * *} \\
{[0.017]}\end{array}$ \\
\hline White owner & $\begin{array}{l}0.267 * * * \\
{[0.006]}\end{array}$ & $\begin{array}{l}0.360 * * * \\
{[0.007]}\end{array}$ & $\begin{array}{l}0.386 * * * \\
{[0.009]}\end{array}$ & $\begin{array}{l}0.398 * * * \\
{[0.006]}\end{array}$ \\
\hline Other race owner & $\begin{array}{l}-0.098 \\
{[0.115]}\end{array}$ & $\begin{array}{l}-0.300^{*} \\
{[0.160]}\end{array}$ & $\begin{array}{l}-0.734 * \\
{[0.424]}\end{array}$ & $\begin{array}{l}-0.531 * * * \\
{[0.183]}\end{array}$ \\
\hline Median income (zip code) & $\begin{array}{l}0.000 * * * \\
{[0.000]}\end{array}$ & $\begin{array}{l}0.000 * * * \\
{[0.000]}\end{array}$ & $\begin{array}{l}0.000 * * * \\
{[0.000]}\end{array}$ & $\begin{array}{l}0.000 * * * \\
{[0.000]}\end{array}$ \\
\hline$\%$ Bachelors (zip code) & $\begin{array}{c}-0.066 \\
{[0.058]}\end{array}$ & $\begin{array}{c}-0.108 \\
{[0.066]}\end{array}$ & $\begin{array}{l}-0.086 \\
{[0.099]}\end{array}$ & $\begin{array}{l}0.074 \\
{[0.069]}\end{array}$ \\
\hline \% Rural (zip code) & $\begin{array}{l}-0.149 * * * \\
{[0.010]}\end{array}$ & $\begin{array}{l}-0.112 * * * \\
{[0.019]}\end{array}$ & $\begin{array}{l}-0.156 * * * \\
{[0.028]}\end{array}$ & $\begin{array}{l}-0.100 * * * \\
{[0.032]}\end{array}$ \\
\hline Jobs reported & $\begin{array}{l}0.023 * * * \\
{[0.000]}\end{array}$ & $\begin{array}{l}0.022 * * * \\
{[0.000]}\end{array}$ & $\begin{array}{l}0.022 * * * \\
{[0.000]}\end{array}$ & $\begin{array}{l}0.021 * * * \\
{[0.000]}\end{array}$ \\
\hline Veteran & $\begin{array}{l}0.855^{* * *} \\
{[0.034]}\end{array}$ & $\begin{array}{l}1.014 * * * \\
{[0.043]}\end{array}$ & $\begin{array}{l}0.930 * * * \\
{[0.050]}\end{array}$ & $\begin{array}{l}1.017 * * * \\
{[0.038]}\end{array}$ \\
\hline Female owner & $\begin{array}{l}0.519 * * * \\
{[0.033]}\end{array}$ & $\begin{array}{l}0.646 * * * \\
{[0.041]}\end{array}$ & $\begin{array}{l}0.598 * * * \\
{[0.047]}\end{array}$ & $\begin{array}{l}0.672 * * * \\
{[0.037]}\end{array}$ \\
\hline Mills ratio & $\begin{array}{l}-0.967 * * * \\
{[0.050]}\end{array}$ & $\begin{array}{l}-1.232 * * * \\
{[0.067]}\end{array}$ & $\begin{array}{l}-1.166 * * * \\
{[0.079]}\end{array}$ & $\begin{array}{l}-1.340^{* * * *} \\
{[0.064]}\end{array}$ \\
\hline Corporate form dummies & Yes & Yes & Yes & Yes \\
\hline 2-Digit NAICS dummies & Yes & Yes & Yes & Yes \\
\hline State dummies & Yes & Yes & Yes & Yes \\
\hline Observations & 949,920 & 911,154 & 773,230 & $1,769,405$ \\
\hline R-squared & 0.357 & 0.343 & 0.342 & 0.331 \\
\hline
\end{tabular}

of owner is about 90 percent). Approximately $0.3 \%$ of loan recipients self-reported as Black (representing approximately 16,000 loans), $0.8 \%$ self-reported as Hispanic (representing approximately 39,000 loans), $1.2 \%$ self-reported as Asian (representing approximately 56,000 loans) and approximately $8 \%$ self-reported as White (representing approximately 388,000 loans). It is notable that most loan recipients did not report race. Panel B reports data from the subsample of loans for which race is reported (of which there are approximately 500,000). Some notable differences include the higher mean loan amount and higher mean jobs reported for the sub-sample of loans for which race is reported. This suggests a selection issue that will need to be addressed in our econometrics, as described below.
In Table 2, we assess the demographic characteristics of the zip codes for the recipients that did not report race, as well as other loan-level information. Column 1 includes only demographic information, Column 2 adds in additional loan-level information, Column 3 adds indicators for industry (at the 2-digit NAICS level), Column 4 adds in indicators for state in which the loan recipient is based, and Column 5 replicates Column 4 after dropping the loan amount. We exclude percent of the population that is White, so the variables for race can be interpreted as relative to White population. Looking at the coefficients for each variable across the columns, there are some interesting patterns. First, recipients appear less likely to report race when in higher income, more educated, and less rural areas. Second, many of the race variables drop in magnitude 
Table 7 PPP loan results, by timing of grant

\begin{tabular}{|c|c|c|c|c|c|c|c|}
\hline & (1) & (2) & (3) & (4) & (5) & (6) & (7) \\
\hline \multicolumn{8}{|c|}{ Dependent variable: Ln loan amount } \\
\hline & Pre-May 1 & Early May & Late May & Early June & Late June & Early July & Late July \\
\hline Asian owner & $\begin{array}{l}-0.037 * * * \\
{[0.007]}\end{array}$ & $\begin{array}{l}0.069 * * * \\
{[0.018]}\end{array}$ & $\begin{array}{l}0.043 * \\
{[0.025]}\end{array}$ & $\begin{array}{l}0.008 \\
{[0.030]}\end{array}$ & $\begin{array}{l}0.056^{* *} \\
{[0.024]}\end{array}$ & $\begin{array}{l}0.014 \\
{[0.057]}\end{array}$ & $\begin{array}{l}0.046 \\
{[0.034]}\end{array}$ \\
\hline Black owner (H3) & $\begin{array}{l}-0.099 * * * \\
{[0.014]}\end{array}$ & $\begin{array}{l}-0.040 \\
{[0.027]}\end{array}$ & $\begin{array}{l}-0.021 \\
{[0.034]}\end{array}$ & $\begin{array}{l}0.066 \\
{[0.045]}\end{array}$ & $\begin{array}{l}0.071 * * \\
{[0.031]}\end{array}$ & $\begin{array}{l}0.129 * \\
{[0.066]}\end{array}$ & $\begin{array}{l}0.115 * * \\
{[0.047]}\end{array}$ \\
\hline Hispanic owner & $\begin{array}{l}0.133 * * * \\
{[0.010]}\end{array}$ & $\begin{array}{l}0.093 * * * \\
{[0.019]}\end{array}$ & $\begin{array}{l}0.098 * * * \\
{[0.025]}\end{array}$ & $\begin{array}{l}0.144 * * * \\
{[0.032]}\end{array}$ & $\begin{array}{l}0.170 * * * \\
{[0.024]}\end{array}$ & $\begin{array}{l}0.011 \\
{[0.066]}\end{array}$ & $\begin{array}{l}0.096 * * \\
{[0.039]}\end{array}$ \\
\hline White owner & $\begin{array}{l}0.287 * * * \\
{[0.003]}\end{array}$ & $\begin{array}{l}0.147 * * * \\
{[0.009]}\end{array}$ & $\begin{array}{l}0.148 * * * \\
{[0.014]}\end{array}$ & $\begin{array}{l}0.234 * * * \\
{[0.018]}\end{array}$ & $\begin{array}{l}0.217 * * * \\
{[0.013]}\end{array}$ & $\begin{array}{l}0.172 * * * \\
{[0.031]}\end{array}$ & $\begin{array}{l}0.166^{* * * *} \\
{[0.019]}\end{array}$ \\
\hline Other race owner & $\begin{array}{c}-0.684 \\
{[0.899]}\end{array}$ & & $\begin{array}{l}0.081 \\
{[0.195]}\end{array}$ & $\begin{array}{l}0.252 * \\
{[0.151]}\end{array}$ & $\begin{array}{l}0.14 \\
{[0.110]}\end{array}$ & $\begin{array}{l}0.482 \\
{[0.435]}\end{array}$ & $\begin{array}{l}0.489 * \\
{[0.288]}\end{array}$ \\
\hline Median income (zip code) & $\begin{array}{l}0.000 * * * \\
{[0.000]}\end{array}$ & $\begin{array}{l}0.000 * * * \\
{[0.000]}\end{array}$ & $\begin{array}{l}0.000 * * * \\
{[0.000]}\end{array}$ & $\begin{array}{l}0.000 * * * \\
{[0.000]}\end{array}$ & $\begin{array}{l}0.000 * * * \\
{[0.000]}\end{array}$ & $\begin{array}{l}0.000 * * * \\
{[0.000]}\end{array}$ & $\begin{array}{l}0.000 * * * \\
{[0.000]}\end{array}$ \\
\hline \% Bachelors (zip code) & $\begin{array}{l}0.107 * * * \\
{[0.036]}\end{array}$ & $\begin{array}{l}0.265 * * * \\
{[0.037]}\end{array}$ & $\begin{array}{l}0.121 * * * \\
{[0.043]}\end{array}$ & $\begin{array}{l}0.107 * \\
{[0.056]}\end{array}$ & $\begin{array}{l}-0.090 * * \\
{[0.044]}\end{array}$ & $\begin{array}{l}-0.376^{* * * *} \\
{[0.075]}\end{array}$ & $\begin{array}{l}-0.432 * * * \\
{[0.052]}\end{array}$ \\
\hline \% Rural (zip code) & $\begin{array}{l}-0.366^{* * *} \\
{[0.008]}\end{array}$ & $\begin{array}{l}-0.091 * * * \\
{[0.012]}\end{array}$ & $\begin{array}{l}-0.091 * * * \\
{[0.017]}\end{array}$ & $\begin{array}{l}-0.085^{* * * *} \\
{[0.022]}\end{array}$ & $\begin{array}{l}-0.133 * * * \\
{[0.016]}\end{array}$ & $\begin{array}{l}-0.109 * * * \\
{[0.035]}\end{array}$ & $\begin{array}{l}-0.088^{* * * *} \\
{[0.021]}\end{array}$ \\
\hline Jobs reported & $\begin{array}{l}0.020 * * * \\
{[0.000]}\end{array}$ & $\begin{array}{l}0.019 * * * \\
{[0.001]}\end{array}$ & $\begin{array}{l}0.022 * * * \\
{[0.001]}\end{array}$ & $\begin{array}{l}0.022 * * * \\
{[0.001]}\end{array}$ & $\begin{array}{l}0.020 * * * \\
{[0.001]}\end{array}$ & $\begin{array}{l}0.030 * * * \\
{[0.004]}\end{array}$ & $\begin{array}{l}0.024 * * * \\
{[0.001]}\end{array}$ \\
\hline Veteran & $\begin{array}{l}0.803 * * * \\
{[0.021]}\end{array}$ & $\begin{array}{l}0.695 * * * \\
{[0.046]}\end{array}$ & $\begin{array}{l}0.756^{* * * *} \\
{[0.070]}\end{array}$ & $\begin{array}{l}0.660 * * * \\
{[0.098]}\end{array}$ & $\begin{array}{l}0.585 * * * \\
{[0.065]}\end{array}$ & $\begin{array}{l}1.017 * * * \\
{[0.169]}\end{array}$ & $\begin{array}{l}1.012 * * * \\
{[0.100]}\end{array}$ \\
\hline Female owner & $\begin{array}{l}0.480 * * * \\
{[0.021]}\end{array}$ & $\begin{array}{l}0.367 * * * \\
{[0.038]}\end{array}$ & $\begin{array}{l}0.355 * * * \\
{[0.057]}\end{array}$ & $\begin{array}{l}0.309 * * * \\
{[0.076]}\end{array}$ & $\begin{array}{l}0.206 * * * \\
{[0.051]}\end{array}$ & $\begin{array}{l}0.670 * * * \\
{[0.128]}\end{array}$ & $\begin{array}{l}0.655 * * * \\
{[0.078]}\end{array}$ \\
\hline Mills ratio & $\begin{array}{l}-1.021 * * * \\
{[0.033]}\end{array}$ & $\begin{array}{l}-0.748 * * * \\
{[0.064]}\end{array}$ & $\begin{array}{l}-0.809 * * * \\
{[0.099]}\end{array}$ & $\begin{array}{l}-0.760 * * * \\
{[0.136]}\end{array}$ & $\begin{array}{l}-0.742 * * * \\
{[0.092]}\end{array}$ & $\begin{array}{l}-1.436 * * * \\
{[0.220]}\end{array}$ & $\begin{array}{l}-1.385^{* * * *} \\
{[0.131]}\end{array}$ \\
\hline Corporate form dummies & Yes & Yes & Yes & Yes & Yes & Yes & Yes \\
\hline 2-Digit NAICS dummies & Yes & Yes & Yes & Yes & Yes & Yes & Yes \\
\hline State dummies & Yes & Yes & Yes & Yes & Yes & Yes & Yes \\
\hline Observations & $3,142,619$ & 429,427 & 170,402 & 95,896 & 227,700 & 47,551 & 133,746 \\
\hline R-squared & 0.347 & 0.217 & 0.226 & 0.217 & 0.183 & 0.176 & 0.173 \\
\hline
\end{tabular}

Standard errors in brackets

${ }^{* * *} p<0.01,{ }^{* *} p<0.05,{ }^{*} p<0.1$

or even switch signs when adding in the state dummies. Third, the higher the loan amount and the more jobs reported, the less likely the recipient is to leave race unanswered (i.e., the more likely the recipient is to report race). We drop loan amount in Column 5 because we use the results from this regression to construct a Heckman selection variable (Mills Ratio) that we include in some of our regression results below to account for selection into self-reporting of race.

\subsection{Methods}

To test our hypotheses, we run a series of regressions using the data described above. The regressions are of the following form:

$\ln \left(\right.$ loanamount $\left._{i z}\right)=\beta_{0}+\beta_{1}$ Black $_{i}+X_{i z} B+\varepsilon_{i z}$

for loan recipient $i$ in zip code $z$. The dependent variable, loan amount, has been transformed as has been described in the prior sub-section. The main independent variable of interest Black is an indicator for whether the loan recipient self-reported as Black. 
We include a variety of firm level, loan level, and zip code level control variables $\boldsymbol{X}$, including gender, veteran status, jobs reported, and dummy variables for industry (at the 2-digit NAICS code level) and state. Data on jobs reported are an important control for variance in firm size that may be correlated with the race of business owners. Black-owned businesses tend to be smaller in size employing fewer workers (Tareque et al., 2021). Since PPP loan amounts are a function of firm payroll, we would expect smaller firms to qualify for smaller loans. By controlling for reported jobs, we can estimate the average difference in loan amounts given to Black and White firms of comparable size.

It is also important to control for industry level effects, given evidence that the pandemic has differentially affected sectors of the economy. For example, data from Yelp suggests that retail establishments have struggled to stay open, whereas professional service establishments such as law firms and accountants have not. ${ }^{8}$ It is important to control for state, given that states instituted different policies in response to the pandemic. We use robust standard errors, clustered at the zip code. For hypothesis 1 , we expect that $\beta_{1}<0$. For hypotheses 2 and 3, we split the sample (based on number of bank branches for hypothesis 2 and timing of loan approval for hypothesis 3), run (1) separately for each sub-sample, and compare the coefficients on $\beta_{1}$ across the sub-samples.

There are two issues with our approach. First, our data is cross-sectional; it provides us with demographic, geographic, and industry characteristics of the borrower, as well as the loan amount. We do not have a natural experiment that we can use to tease out causal effects of race on loan amounts. Instead, we use our regressions to control for as many observable differences across borrowers as we can. Second, there is a lot of non-response on the race of owner variable-as reported above, only about $10 \%$ of loans report race of owner. This potentially introduces a selection bias if, for example, Black borrowers that receive larger loans are systematically more likely to not report race than White borrowers that receive large loans. We have no reason to believe that to be the case, but in order to address the selection issue and account for unanswered race, we include a Heckman selection correction term-the Mills ratio-in all our regressions. The construction of the Mills ratio is described in the prior sub-section. Note that we included county-level demographic variables in the construction of our Mills ratio that we do not include our regressions. We also provide results on the full sample, in which case unanswered race is the excluded category, and (in an Appendix) on the smaller sub-sample that provides information on race, in which case White is the excluded category.

\section{Results}

Before turning to regression results, we first aggregate the loan data to the national level. These results are presented in Table 3. The average loan per recipient ("Org") for Black recipients is $\$ 82,660$. This is about $13 \%$ less than recipients who report race as unanswered $(\$ 94,602)$ and about $37 \%$ less than White recipients $(\$ 131,313)$. Of course, these differences could be reflective of many other factors, including the industry in which the business operates, the region of the country, the size of the business, and others. In order to systematically account for these factors, we next turn to our regression results.

Next, we consider how the lender characteristics evolved over time. For this, we compare loans made by a "Top 5 bank" and a "Top 5 alternative lender" before and after April 30, 2020. A "Top 5 bank" indicates that the lender was one of Bank of America, JP Morgan Chase, Wells Fargo, U.S. Bank, or Citibank. These banks are the largest U.S. commercial banks by deposits, and the first three of those accounted for approximately $12 \%$ of all PPP loans made. A "Top 5 alternative lender" indicates that the lender was one of Cross River Bank, Kabbage, Celtic Bank, WebBank, or Customer's Bank. Kabbage is a fintech bank based in Georgia. The other banks are the lenders behind leading fintech lenders such as Coinbase and RocketLoans (Cross River), Square and OnDeck (Celtic Bank), LoanBuilder.com (WebBank), and Upstart (Customer's Bank), to name a few. We classify these five banks as "alternative" as they are not traditional depository institutions like the Top 5 banks. Cross River and Kabbage together account for approximately $6 \%$ of all PPP loans made. We report results in Table 4. Panel A of this table indicates that prior to April 30, about $19 \%$ of all loans were made by a

\footnotetext{
8 https://www.yelpeconomicaverage.com/business-closuresupdate-sep-2020.
} 
Top 5 bank, whereas only about $5 \%$ were made by a Top 5 alternative. However, this changes after April 30. Top 5 banks still account for about $19 \%$ of all loans (though there are fewer loans made after April 30), but Top 5 alternative lenders account for approximately $30 \%$ of all loans - a dramatic increase. Panel B of this table indicates that prior to April 30, the Top 5 alternative lenders made 444 loans to White borrowers and 30 to Black borrowers, whereas after April 30 the Top 5 alternative lenders made 2525 loans to White borrowers and 636 to Black borrowers. This amounts to about a $6 \times$ increase in loans to White borrowers and a $21 \times$ increase in loans to Black borrowers. Thus, the Top 5 alternative lenders increased loans to both White and Black borrowers, but much more to Black borrowers on a proportional basis.

In Table 5, we present our main results (Eq. (1)). In Column 1 we include only loan-level race variables, in Column 2 we add in zip code level demographics, in Column 3 we add in other loan-level variables, in Column 4 we add in dummy variables for 2-digit NAICS code, in Column 5 we add in dummy variables for the state, and in Column 6 we add in the Mills Ratio to correct for selection. All the coefficients are quite stable across the various specifications. The coefficient on Black is negative and statistically significant across all the specifications. Since our dependent variable is logged, we can interpret the coefficient in terms of percentage changes. The coefficients suggest that Black borrowers received loans that were 14 to $16 \%$ smaller than those of borrowers who did not answer their race. These estimates from our loan-level regressions line up closely with what we observe from the national-level statistics presented in Table 3. To assess the difference between Black and White borrowers, we can assess the difference between the coefficients on these two variables. The coefficient on Black in Column 6, the fully specified model, is -0.162 ; the coefficient on White in Column 6 is 0.357 . The difference is approximately 0.519 , suggesting that loans to Black borrowers were about $50 \%$ lower than observationally similar White borrowers. Appendix Table 9 replicates the specifications in Table 5, but on the sample of borrowers that report race (White is the excluded category in Appendix Table 9). The coefficient on Black in Column 6 of Appendix Table 9 is -0.550 , suggesting that loans to Black borrowers were about 55\% lower than observationally similar White borrowers. These figures are larger than the figures obtained from the aggregated statistics presented in Table 3, suggesting that compositional factors (such as location, size and industry) mask some of the difference in loans received by White and Black borrowers. Overall, the results from Table 5 provide support for $\mathrm{H} 1$.

Next, we consider how the main result varies depending on the presence of bank branches. Table 6 presents results from a series of split-samples. Column 1 replicates Column 6 from Table 5 on the subsample of zip codes that have 1-3 bank branches, Column 2 does the same but on the sub-sample of zip codes that have 4-6 bank branches, Column 3 does the same on the sub-sample of zip codes that have 7-9 bank branches, and Column 4 is for the sub-sample of zip codes that have 10 or more bank branches. The coefficient on Black in Column $4(-0.104)$ is larger than the coefficient on Black in Column $1(-0.241)$, suggesting that higher numbers of bank branches helps to attenuate the main effect.

Some care needs to be taken when interpreting these results, however. In Table 6, the coefficient on White also increases when increasing the number of bank branches (0.267 in Column 1 and 0.398 in Column 4), suggesting that everyone benefits from larger loans as the number of bank branches increases. To understand whether the differential between Black and White borrowers changes, we compare the differences in Black and White coefficients in each case. The difference in Column $1(0.267-(-0.241))$ is 0.508 . The difference in Column $4(0.398-(-0.104))$ is 0.502 . The difference between these two is quite small (0.006), and not statistically significant based on the standard errors. To see this more directly, we can look at the coefficient on Black for the equivalent split-sample regressions on the subsample of loans for which race is reported, which is presented in Appendix Table 10. The coefficient on Black goes from-0.587 in Column 1 to-0.507 in Column 4. Again the difference between these two is quite small (0.08). Overall, the results presented in Table 6 and in Appendix Table 10 are directionally consistent with what we expect from $\mathrm{H} 2$, but not statistically significant.

Finally, we consider how the main result varies depending on timing. Table 7 Column 1 replicates Column 6 from Table 5 on the sub-sample of loans that were approved before April 30, 2020. The coefficient on Black in Column 1 is negative and statistically significant. Recall from Table 4 that there are relatively few loans made by alternative lenders during this time period. Columns 27 repeat the analysis but for the six 
2-week periods following April 30 until the end of July. It is notable that the coefficient on Black almost monotonically increases in each successive time period. By late June, the coefficient on Black is positive and statistically significant. Over this same time period, the coefficient on White remains positive and statistically significant, but declines in magnitude. By late July, the coefficients on Black and White are nearly identical from a statistical standpoint. ${ }^{9}$ Recall from Table 4 that there is a large increase in the percent of loans made by alternative lenders during this time period, and that alternative lenders dramatically increased the proportion of loans to Black borrowers. Overall, the results presented in Table 7 provide support for our H3. In Appendix 4 we replicate the results on the sub-sample for which race was reported.

\section{Conclusion}

We show that the PPP loan program produced different outcomes for Black and White business owners. Specifically, Black-owned firms were approved for smaller loans than their White counterparts controlling for observed characteristics. We also show that SBA reliance on commercial banks to administer the program drives this outcome in two ways. First, Black-White disparities in PPP loans appear (marginally) greater in areas with fewer bank branches where Black firm owners may have been less likely to have prior relationships with SBA approved lenders. Second, the Black-White disparities in PPP loans decreased during the second round of funding when more non-bank entities were approved by SBA to participate in the program.

Data limited the scope of our analysis. Data on the race of business owner was only available for $10 \%$ of loan recipients, potentially creating selection bias. We address this by conducting our analyses for the entire sample as well as the sub-sample for which race is reported, and by including a Mills ratio from a first-stage Heckman selection approach to control for potential selection bias. Also, we were unable to examine lending discrimination in loan approval rates since SBA did not require reporting on all loan applicants. More research is needed to determine whether

\footnotetext{
9 The difference between Black and White coefficients is 0.05 and the sum of the standard errors is 0.063 . The ratio of the two is less than 2, indicating one cannot reject that the difference is 0 .
}

Black firm owners were denied loans disproportionately. While our results are consistent with lending discrimination, we cannot directly observe discrimination in the data. We are however able to show that the PPP loan program produced disparate outcomes for Black and White business owners.

Our study makes several contributions to the literature. It joins the growing corpus on the PPP program and the larger body of work on government responses to crises such as the Covid-19 pandemic. While prior work examined whether PPP loans were reaching predominately Black neighborhoods at the zip code or census tract level (Calem \& Freedman, 2020; Fairlie \& Fossen, 2021), our study evaluates differences in PPP loan sizes granted to Black business owners as compared with White business owners. Prior work shows that Black-owned firms closed at a higher rate than others due to the pandemic (Fairlie, 2020). Our study suggests that one possible explanation is inadequate access to PPP funds, a vital source of relief for many small businesses. Our analysis highlights the need for policy makers to account for embedded inequalities when using existing systems to administer relief programs.

Our paper also contributes to the literature on minority-owned business finance and access to capital. We confirm prior findings that Black-owned firms tend to be approved for smaller loans than White-owned firms, controlling for observed characteristics. We extend the literature by examining whether density of local bank branches and access to more non-bank lenders alter outcomes for Black-owned firms. Future research should examine the mechanisms through which non-profit, community development, minority development, and fintech lenders supply additional capital to Black business owners in contrast to commercial banking institutions.

A few possible policy interventions seem warranted. First, in preparation for the next financial crisis or national emergency, racial disparities in lending through traditional financial institutions need to be investigated and addressed by the various regulators who oversee these institutions. Discriminatory lending and banking practices should not be allowed to stand anywhere in the financial system. Second, the next SBA Inspector General's report should include a systematic accounting of the factors negatively affecting the participation of Black business owners in the PPP. In general, between financial and economic crises, the SBA infrastructure and capacity should be increased such that all loans, whether standard or emergency, can be processed significantly 
more quickly than is currently the case. Fourth, ex ante demographic data collection should be applied to PPP loans and other emergency funding facilities going forward. This is standard for other SBA loans and will help with targeting funding better in the future. Finally, serious consideration should be given to increasing the capacity of CDFIs to reach and service businessowners in underserved communities.

\section{Appendix}

Please see Tables 8, 9, 10, 11

Table 8 PPP loan-level results, on full sample, no Winsorizing

\begin{tabular}{|c|c|c|c|c|c|c|}
\hline & (1) & (2) & (3) & (4) & (5) & (6) \\
\hline \multicolumn{7}{|c|}{ Dependent variable: Ln loan amount (no winsorizing) } \\
\hline Asian owner & $\begin{array}{l}0.247 * * * \\
{[0.011]}\end{array}$ & $\begin{array}{l}0.233 * * * \\
{[0.011]}\end{array}$ & $\begin{array}{l}0.070 * * * \\
{[0.008]}\end{array}$ & $\begin{array}{l}0.044 * * * \\
{[0.007]}\end{array}$ & $\begin{array}{l}0.028 * * * \\
{[0.007]}\end{array}$ & $\begin{array}{l}0.022 * * * \\
{[0.007]}\end{array}$ \\
\hline Black owner (H1) & $\begin{array}{l}-0.148 * * * \\
{[0.016]}\end{array}$ & $\begin{array}{l}-0.142 * * * \\
{[0.016]}\end{array}$ & $\begin{array}{l}-0.162 * * * \\
{[0.012]}\end{array}$ & $\begin{array}{l}-0.144 * * * \\
{[0.012]}\end{array}$ & $\begin{array}{l}-0.141 * * * \\
{[0.011]}\end{array}$ & $\begin{array}{l}-0.165^{* * *} \\
{[0.011]}\end{array}$ \\
\hline Hispanic owner & $\begin{array}{l}0.150 * * * \\
{[0.015]}\end{array}$ & $\begin{array}{l}0.148 * * * \\
{[0.015]}\end{array}$ & $\begin{array}{l}0.074 * * * \\
{[0.011]}\end{array}$ & $\begin{array}{l}0.044 * * * \\
{[0.011]}\end{array}$ & $\begin{array}{l}0.102 * * * \\
{[0.010]}\end{array}$ & $\begin{array}{l}0.085^{* * * *} \\
{[0.009]}\end{array}$ \\
\hline White owner & $\begin{array}{l}0.426^{* * * *} \\
{[0.006]}\end{array}$ & $\begin{array}{l}0.499 * * * \\
{[0.006]}\end{array}$ & $\begin{array}{l}0.360 * * * \\
{[0.004]}\end{array}$ & $\begin{array}{l}0.330 * * * \\
{[0.004]}\end{array}$ & $\begin{array}{l}0.345^{* * * *} \\
{[0.003]}\end{array}$ & $\begin{array}{l}0.353 * * * \\
{[0.003]}\end{array}$ \\
\hline Other race owner & $\begin{array}{l}-1.119 * * * \\
{[0.088]}\end{array}$ & $\begin{array}{l}-1.120 * * * \\
{[0.092]}\end{array}$ & $\begin{array}{l}-0.749 * * * \\
{[0.087]}\end{array}$ & $\begin{array}{l}-0.824 * * * \\
{[0.084]}\end{array}$ & $\begin{array}{l}-0.273 * * * \\
{[0.088]}\end{array}$ & $\begin{array}{l}-0.290^{* * * *} \\
{[0.088]}\end{array}$ \\
\hline Median income (zip code) & & $\begin{array}{l}0.000 * * * \\
{[0.000]}\end{array}$ & $\begin{array}{l}0.000 * * * \\
{[0.000]}\end{array}$ & $\begin{array}{l}0.000 * * * \\
{[0.000]}\end{array}$ & $\begin{array}{l}0.000 * * * \\
{[0.000]}\end{array}$ & $\begin{array}{l}0.000^{* * * *} \\
{[0.000]}\end{array}$ \\
\hline \% Bachelors (zip code) & & $\begin{array}{l}0.219 * * * \\
{[0.050]}\end{array}$ & $\begin{array}{l}0.360 * * * \\
{[0.038]}\end{array}$ & $\begin{array}{l}0.415 * * * \\
{[0.036]}\end{array}$ & $\begin{array}{l}0.344 * * * \\
{[0.034]}\end{array}$ & $\begin{array}{l}0.172 * * * \\
{[0.036]}\end{array}$ \\
\hline \% Rural (zip code) & & $\begin{array}{l}-0.499 * * * \\
{[0.012]}\end{array}$ & $\begin{array}{l}-0.311 * * * \\
{[0.009]}\end{array}$ & $\begin{array}{l}-0.319 * * * \\
{[0.008]}\end{array}$ & $\begin{array}{l}-0.309 * * * \\
{[0.008]}\end{array}$ & $\begin{array}{l}-0.213^{* * * *} \\
{[0.008]}\end{array}$ \\
\hline Jobs reported & & & $\begin{array}{l}0.023 * * * \\
{[0.000]}\end{array}$ & $\begin{array}{l}0.023 * * * \\
{[0.000]}\end{array}$ & $\begin{array}{l}0.022 * * * \\
{[0.000]}\end{array}$ & $\begin{array}{l}0.023 * * * \\
{[0.000]}\end{array}$ \\
\hline Veteran & & & $\begin{array}{l}0.292 * * * \\
{[0.007]}\end{array}$ & $\begin{array}{l}0.266^{* * * *} \\
{[0.007]}\end{array}$ & $\begin{array}{l}0.255^{* * *} \\
{[0.007]}\end{array}$ & $\begin{array}{l}0.884 * * * \\
{[0.021]}\end{array}$ \\
\hline Female owner & & & $\begin{array}{l}-0.125 * * * \\
{[0.003]}\end{array}$ & $\begin{array}{l}-0.104^{* * * *} \\
{[0.003]}\end{array}$ & $\begin{array}{l}-0.099 * * * \\
{[0.003]}\end{array}$ & $\begin{array}{l}0.539 * * * \\
{[0.020]}\end{array}$ \\
\hline Mills ratio & & & & & & $\begin{array}{l}-1.064 * * * \\
{[0.033]}\end{array}$ \\
\hline Corporate form dummies & & & Yes & Yes & Yes & Yes \\
\hline 2-Digit NAICS dummies & & & & Yes & Yes & Yes \\
\hline State dummies & & & & & Yes & Yes \\
\hline Observations & $4,855,504$ & $4,833,100$ & $4,516,503$ & $4,403,730$ & $4,403,710$ & $4,403,708$ \\
\hline R-squared & 0.007 & 0.016 & 0.319 & 0.353 & 0.360 & 0.361 \\
\hline
\end{tabular}

Standard errors in brackets

**** $p<0.01,{ }^{* *} p<0.05,{ }^{*} p<0.1$ 
Table 9 PPP loan-level results, on sub-sample reporting race
(1)
(2)
(3)

[0.006]

$-0.568 * * *$

[0.012]

$-0.272 * * *$

[0.008]

$-1.537 * * *$

[0.115]

Jobs reported

Veteran

Female owner

Mills ratio

Corporate form dummies

2-Digit NAICS dummies

State dummies

Observations

502,807

0.008
$-0.373^{* * *}$

[0.006]

$-0.728 * *$

[0.011]

$-0.448^{* * *}$

[0.008]

$-1.742 * * *$

[0.114]

$0.000 * * *$

[0.000]

$0.409 * * *$

[0.025]

$-1.026^{* * *}$

[0.008]

500,096

$-0.380 * * *$

[0.005]

$-0.557 * * *$

[0.009]

$-0.345^{* * * *}$

[0.006]

$-1.227 * * *$

[0.094]

$0.000 * * *$

[0.000]

$0.460 * * *$

[0.021]

$-0.676^{* * *}$

[0.006]

$0.022 * * *$

[0.000]

$0.074 * * *$

[0.009]

$-0.306 * * *$

[0.004]

486,827

0.061

0.375
(4)
$-0.377 * * *$

[0.005]

$-0.534 * * *$

[0.009]

$-0.350 * * *$

[0.006]

$-1.265^{* * *}$

[0.093]

$0.000 * * *$

[0.000]

0.580 ***

[0.021]

$-0.597 * * *$

[0.006]

$0.021 * * *$

[0.000]

$0.059 * * *$

[0.009]

$-0.275 * * *$

[0.004]

Yes

Yes

486,625

$-0.445 * * *$

[0.006]

$-0.548 * * *$

[0.009]

$-0.338^{* * *}$

[0.006]

$-0.671^{* * *}$

[0.093]

$0.000 * * *$

[0.000]

$0.517 * * *$

[0.021]

$-0.510 * * *$

[0.007]

$0.021 * * *$

[0.000]

$0.035 * * *$

[0.009]

$-0.270 * * *$

[0.004]

0.408
$-0.446 * * *$

[0.006]

$-0.550 * * *$

[0.009]

$-0.340 * * *$

[0.006]

$-0.670^{* * *}$

[0.093]

$0.000 * * *$

[0.000]

$0.482 * * *$

[0.022]

$-0.495 * * *$

[0.007]

$0.021 * * *$

[0.000]

$0.122 * * *$

[0.018]

$-0.182 * * *$

[0.017]

$-0.139 * * *$

[0.026]

Yes

Yes

Yes

486,625

0.419

Standard errors in brackets

${ }^{* * * *} p<0.01,{ }^{* *} p<0.05,{ }^{*} p<0.1$ 
Table 10 PPP loan results, alternate split by num bank branches, on sample reporting race

\section{(1)}

(2)

(3)

(4)

Dependent variable: Ln loan amount

Number of branches:

Asian owner

$$
1-3
$$

$-0.451 * * *$

[0.016]

Black owner (H2)

$-0.587 * * *$

[0.022]

Hispanic owner

$-0.339 * * *$

[0.019]

Other race owner

$-0.387 * * *$

[0.126]

Median income (zip code)

0.000

[0.000]

\% Bachelors (zip code)

$0.480 * * *$

[0.078]

$\%$ Rural (zip code)

Jobs reported

Veteran

Female owner

Mills ratio

$$
-0.430 * * *
$$$$
\text { [0.017] }
$$

$0.024 * * *$

[0.000]

$0.077 *$

[0.042]

$-0.204 * * *$

[0.040]

$-0.052$

[0.058]

Corporate form dummies

Yes

2-Digit NAICS dummies

Yes

Yes

State dummies

124,920

0.450
4-6

$-0.457 * * *$

[0.016]

$-0.541 * * *$

[0.024]

$-0.338^{* * *}$

[0.019]

$-0.688 * * *$

[0.155]

$0.000 * *$

[0.000]

$0.354 * * *$

[0.093]

$-0.458 * * *$

[0.030]

$0.021 * * *$

[0.000]

$0.256 * * *$

[0.050]

$-0.061$

[0.046]

$-0.323 * * *$

[0.072]

Yes

Yes

Yes

100,400

0.419
7-9

$-0.432 * * *$

[0.016]

$-0.558 * * *$

[0.027]

$-0.368 * * *$

[0.022]

$-1.295^{* * *}$

[0.408]

$0.000 * * *$

[0.000]

$0.282 * * *$

[0.102]

$-0.565^{* * *}$

[0.053]

$0.020 * * *$

[0.000]

$0.097 *$

[0.058]

$-0.187 * * *$

[0.052]

$-0.151^{*}$

[0.085]

Yes

Yes

Yes

81,885

0.404
$10+$

$-0.440 * * *$

[0.013]

$-0.507 * * *$

[0.019]

$-0.328 * * *$

[0.016]

$-0.929 * * *$

[0.213]

$0.000 * * *$

[0.000]

$0.435 * * *$

[0.070]

$-0.433 * * *$

[0.048]

$0.020 * * *$

[0.000]

0.160 ***

[0.037]

$-0.159 * * *$

[0.034]

$-0.206 * * *$

[0.056]

Yes

Yes

Yes

179,420

0.389

Standard errors in brackets

${ }^{* * *} p<0.01,{ }^{* *} p<0.05,{ }^{*} p<0.1$ 
Table 11 PPP loan results by timing of grant, on sub-sample reporting race

\begin{tabular}{|c|c|c|c|c|c|c|c|}
\hline & (1) & (2) & (3) & (4) & (5) & (6) & (7) \\
\hline \multicolumn{8}{|c|}{ Dependent variable: $\mathrm{Ln}$ loan amount } \\
\hline & Pre-May 1 & Early May & Late May & Early June & Late June & Early July & Late July \\
\hline Asian owner & $\begin{array}{l}-0.408 * * * \\
{[0.008]}\end{array}$ & $\begin{array}{l}-0.199 * * * \\
{[0.022]}\end{array}$ & $\begin{array}{l}-0.220 * * * \\
{[0.032]}\end{array}$ & $\begin{array}{l}-0.338^{* * *} \\
{[0.039]}\end{array}$ & $\begin{array}{l}-0.250 * * * \\
{[0.029]}\end{array}$ & $\begin{array}{l}-0.260 * * * \\
{[0.071]}\end{array}$ & $\begin{array}{l}-0.274 * * * \\
{[0.044]}\end{array}$ \\
\hline Black owner (H3) & $\begin{array}{l}-0.385 * * * \\
{[0.014]}\end{array}$ & $\begin{array}{l}-0.235 * * * \\
{[0.029]}\end{array}$ & $\begin{array}{l}-0.197 * * * \\
{[0.040]}\end{array}$ & $\begin{array}{l}-0.183 * * * \\
{[0.050]}\end{array}$ & $\begin{array}{l}-0.142 * * * \\
{[0.035]}\end{array}$ & $\begin{array}{l}0.031 \\
{[0.080]}\end{array}$ & $\begin{array}{l}0.008 \\
{[0.054]}\end{array}$ \\
\hline Hispanic owner & $\begin{array}{l}-0.208 * * * \\
{[0.010]}\end{array}$ & $\begin{array}{l}-0.100 * * * \\
{[0.023]}\end{array}$ & $\begin{array}{l}-0.100 * * * \\
{[0.031]}\end{array}$ & $\begin{array}{l}-0.164 * * * \\
{[0.041]}\end{array}$ & $\begin{array}{l}-0.098 * * * \\
{[0.030]}\end{array}$ & $\begin{array}{l}-0.184 * * \\
{[0.075]}\end{array}$ & $\begin{array}{l}-0.127 * * * \\
{[0.047]}\end{array}$ \\
\hline Other race owner & $\begin{array}{l}-1.099 \\
{[0.879]}\end{array}$ & & $\begin{array}{l}-0.139 \\
{[0.204]}\end{array}$ & $\begin{array}{l}--0.092 \\
{[0.157]}\end{array}$ & $\begin{array}{l}-0.119 \\
{[0.125]}\end{array}$ & $\begin{array}{l}0.171 \\
{[0.388]}\end{array}$ & $\begin{array}{l}0.217 \\
{[0.285]}\end{array}$ \\
\hline Median income (zip code) & $\begin{array}{l}0.000 * * * \\
{[0.000]}\end{array}$ & $\begin{array}{l}0.000 * * * \\
{[0.000]}\end{array}$ & $\begin{array}{l}0.000 * * * \\
{[0.000]}\end{array}$ & $\begin{array}{l}0.000 * * \\
{[0.000]}\end{array}$ & $\begin{array}{l}0.000 * * \\
{[0.000]}\end{array}$ & $\begin{array}{l}0.000 * * \\
{[0.000]}\end{array}$ & $\begin{array}{l}0 \\
{[0.000]}\end{array}$ \\
\hline \% Bachelors (zip code) & $\begin{array}{l}0.526 * * * \\
{[0.041]}\end{array}$ & $\begin{array}{l}0.536 * * * \\
{[0.097]}\end{array}$ & $\begin{array}{l}0.475 * * * \\
{[0.140]}\end{array}$ & $\begin{array}{l}0.482 * * * \\
{[0.178]}\end{array}$ & $\begin{array}{l}0.188 \\
{[0.123]}\end{array}$ & $\begin{array}{l}0.282 \\
{[0.287]}\end{array}$ & $\begin{array}{l}0.515 * * * \\
{[0.196]}\end{array}$ \\
\hline \% Rural (zip code) & $\begin{array}{l}-0.543 * * * \\
{[0.012]}\end{array}$ & $\begin{array}{l}-0.242 * * * \\
{[0.031]}\end{array}$ & $\begin{array}{l}-0.180 * * * \\
{[0.047]}\end{array}$ & $\begin{array}{l}-0.189 * * * \\
{[0.063]}\end{array}$ & $\begin{array}{l}-0.242 * * * \\
{[0.043]}\end{array}$ & $\begin{array}{l}-0.320 * * * \\
{[0.104]}\end{array}$ & $\begin{array}{l}-0.161 * * \\
{[0.065]}\end{array}$ \\
\hline Jobs reported & $\begin{array}{l}0.020 * * * \\
{[0.000]}\end{array}$ & $\begin{array}{l}0.020 * * * \\
{[0.002]}\end{array}$ & $\begin{array}{l}0.024 * * * \\
{[0.003]}\end{array}$ & $\begin{array}{l}0.025 * * * \\
{[0.004]}\end{array}$ & $\begin{array}{l}0.020 * * * \\
{[0.002]}\end{array}$ & $\begin{array}{l}0.030 * * * \\
{[0.008]}\end{array}$ & $\begin{array}{l}0.022 * * * \\
{[0.004]}\end{array}$ \\
\hline Veteran & $\begin{array}{l}0.099 * * * \\
{[0.023]}\end{array}$ & $\begin{array}{l}0.233 * * * \\
{[0.075]}\end{array}$ & $\begin{array}{l}0.381 * * * \\
{[0.113]}\end{array}$ & $\begin{array}{l}0.25 \\
{[0.154]}\end{array}$ & $\begin{array}{l}0.065 \\
{[0.099]}\end{array}$ & $\begin{array}{c}-0.074 \\
{[0.255]}\end{array}$ & $\begin{array}{l}0.240 * \\
{[0.145]}\end{array}$ \\
\hline Female owner & $\begin{array}{l}-0.189 * * * \\
{[0.022]}\end{array}$ & $\begin{array}{c}-0.04 \\
{[0.064]}\end{array}$ & $\begin{array}{l}0.036 \\
{[0.099]}\end{array}$ & $\begin{array}{l}0.031 \\
{[0.132]}\end{array}$ & $\begin{array}{l}-0.198 * * \\
{[0.085]}\end{array}$ & $\begin{array}{l}-0.371 * \\
{[0.207]}\end{array}$ & $\begin{array}{c}-0.098 \\
{[0.116]}\end{array}$ \\
\hline Mills ratio & $\begin{array}{l}-0.114 * * * \\
{[0.034]}\end{array}$ & $\begin{array}{l}-0.271 * * * \\
{[0.104]}\end{array}$ & $\begin{array}{l}-0.378^{* *} \\
{[0.168]}\end{array}$ & $\begin{array}{l}-0.365 \\
{[0.228]}\end{array}$ & $\begin{array}{c}-0.048 \\
{[0.148]}\end{array}$ & $\begin{array}{l}0.391 \\
{[0.354]}\end{array}$ & $\begin{array}{l}-0.132 \\
{[0.198]}\end{array}$ \\
\hline Corporate form dummies & Yes & Yes & Yes & Yes & Yes & Yes & Yes \\
\hline 2-Digit NAICS dummies & Yes & Yes & Yes & Yes & Yes & Yes & Yes \\
\hline State dummies & Yes & Yes & Yes & Yes & Yes & Yes & Yes \\
\hline Observations & 407,927 & 26,005 & 11,447 & 7086 & 15,659 & 2241 & 6720 \\
\hline R-squared & 0.422 & 0.297 & 0.317 & 0.324 & 0.278 & 0.289 & 0.276 \\
\hline
\end{tabular}

Standard errors in brackets

${ }^{* * *} p<0.01,{ }^{* *} p<0.05,{ }^{*} p<0.1$ 


\section{References}

Amiram, D., \& Rabetti, D. (2020). The relevance of relationship lending in times of crisis (SSRN Scholarly Paper ID 3701587). Social Science Research Network. https://doi. org/10.2139/ssrn.3701587

Arrow, K. J. (1998). What has economics to say about racial discrimination? Journal of Economic Perspectives, 12(2), 91-100. https://doi.org/10.1257/jep.12.2.91

Atkins, R. M. B. (2021). Homeownership, home equity, and Black-owned business starts: Examining the impact of racial disparities in housing assets on firm creation. 33.

Bartik, A. W., Bertrand, M., Cullen, Z. B., Glaeser, E. L., Luca, M., \& Stanton, C. T. (2020). How are small businesses adjusting to COVID-19? Early evidence from a survey (No. w26989). National Bureau of Economic Research. https://doi.org/10.3386/w26989

Bates, T. (1989). Small business viability in the urban ghetto*. Journal of Regional Science, 29(4), 625-643. https://doi.org/10.1111/j.1467-9787.1989.tb01248.x

Bates, T., Bradford, W. D., \& Seamans, R. (2018). Minority entrepreneurship in twenty-first century America. Small Business Economics, 50(3), 415-427. https://doi.org/10. 1007/s11187-017-9883-5

Bates, T., \& Robb, A. (2013). Greater access to capital is needed to unleash the local economic development potential of minority-owned businesses. Economic Development Quarterly, 27(3), 250-259. https://doi.org/ $10.1177 / 0891242413477188$

Bates, T., \& Robb, A. (2015). Has the Community Reinvestment Act increased loan availability among small businesses operating in minority neighbourhoods? Urban Studies, 52(9), 1702-1721. https://doi.org/10.1177/ 0042098014534903

Benjamin, L., Rubin, J. S., \& Zielenbach, S. (2004). Community development financial institutions: Current issues and future prospects. Journal of Urban Affairs, 26(2), 177-195. https://doi.org/10.1111/j.0735-2166.2004. 00196.x

Berger, A. N., \& Udell, G. F. (2002). Small business credit availability and relationship lending: The importance of bank organisational structure. The Economic Journal, 112(477), F32-F53. https://doi.org/10.1111/1468-0297. 00682

Blanchard, L., Zhao, B., \& Yinger, J. (2008). Do lenders discriminate against minority and woman entrepreneurs? Journal of Urban Economics, 63(2), 467-497. https://doi. org/10.1016/j.jue.2007.03.001

Blanchflower, D. G., Levine, P. B., \& Zimmerman, D. J. (2003). Discrimination in the small-business credit market. The Review of Economics and Statistics, 85(4), 930943. https://doi.org/10.1162/003465303772815835

Buffington, C., Dennis, C., Dinlersoz, E., Foster, L., \& Klimek, S. (2020). Measuring the effect of COVID-19 on US small businesses. The Small Business Pulse Survey, No. 20-16. https://www.census.gov/library/working-papers/2020/ adrm/CES-WP-20-16.html

Calem, P., \& Freedman, A. (2020). Neighborhood demographics and the allocation of Paycheck Protection Program Funds (SSRN Scholarly Paper ID 3776794). Social
Science Research Network. https://doi.org/10.2139/ssrn. 3776794

Carey, M., Post, M., \& Sharpe, S. A. (1998). Does corporate lending by banks and finance companies differ? Evidence on specialization in private debt contracting. The Journal of Finance, 53(3), 845-878. https://doi.org/10.1111/00221082.00037

Cavalluzzo, K. S., \& Cavalluzzo, L. C. (1998). Market structure and discrimination: The case of small businesses. Journal of Money, Credit and Banking, 30(4), 771-792. https://doi.org/10.2307/2601128

Cavalluzzo, K. S., Cavalluzzo, L. C., \& Wolken, J. D. (2002). Competition, small business financing, and discrimination: Evidence from a new survey. The Journal of Business, 75(4), 641-679. https://doi.org/10.1086/341638

Cavalluzzo, K., \& Wolken, J. (2005). Small business loan turndowns, personal wealth, and discrimination. The Journal of Business, 78(6), 2153-2178. https://doi.org/10.1086/ 497045

Cerqueiro, G., \& Penas, M. F. (2017). How does personal bankruptcy law affect startups? The Review of Financial Studies, 30(7), 2523-2554. https://doi.org/10.1093/rfs/ hhw081

Cerqueiro, G., Penas, M. F., \& Seamans, R. (2019). Debtor protection and business dynamism. The Journal of Law and Economics, 62(3), 521-549. https://doi.org/10.1086/ 704956

Chatterji, A. K., \& Seamans, R. C. (2012). Entrepreneurial finance, credit cards, and race. Journal of Financial Economics, 106(1), 182-195. https://doi.org/10.1016/j.jfine co.2012.04.007

Chen, T., Lin, C., \& Sun, B. (2021). Racial disparities in small business lending (SSRN Scholarly Paper ID 3821442). Social Science Research Network. https://doi.org/10.2139/ ssrn.3821442

Chetty, R., Friedman, J. N., Hendren, N., Stepner, M., \& Team, T. O. I. (2020). The economic impacts of COVID-19: Evidence from a new public database built using private sector data (No. w27431). National Bureau of Economic Research. https://doi.org/10.3386/w27431

Chodorow-Reich, G., Feiveson, L., Liscow, Z., \& Woolston, W. G. (2012). Does state fiscal relief during recessions increase employment? Evidence from the American Recovery and Reinvestment Act. American Economic Journal: Economic Policy, 4(3), 118-145. https://doi.org/ 10.1257/pol.4.3.118

Chugh, D. (2004). Societal and managerial implications of implicit social cognition: Why milliseconds matter. Social Justice Research, 17(2), 203-222. https://doi.org/10. 1023/B:SORE.0000027410.26010.40

Cororaton, A., \& Rosen, S. (2020). Public firm borrowers of the US Paycheck Protection Program (SSRN Scholarly Paper ID 3590913). Social Science Research Network. https://doi.org/10.2139/ssrn.3590913

Couch, K. A., Fairlie, R. W., \& Xu, H. (2020). Early evidence of the impacts of COVID-19 on minority unemployment. Journal of Public Economics, 192, 104287. https://doi. org/10.1016/j.jpubeco.2020.104287

Council of Economic Advisers (2016). Financial inclusion in the United States. July 2016 Issue Brief. https://obama 
whitehouse.archives.gov/sites/default/files/docs/20160 610_financial_inclusion_cea_issue_brief.pdf

Cover, J., Spring, A. F., \& Kleit, R. G. (2011). Minorities on the margins? The spatial organization of fringe banking services. Journal of Urban Affairs, 33(3), 317-344. https://doi.org/10.1111/j.1467-9906.2011.00553.x

da Motta-victor, V. E. (n.d.). Minority-owned enterprises and access to capital from community development financial institutions. Retrieved May 25, 2021, from http://www. anpad.org.br/abrir_pdf.php?e=Mjc4Mjc=

Daniels, K., \& Ramirez, G. G. (2008). Information, credit risk, lender specialization and loan pricing: Evidence from the DIP financing market. Journal of Financial Services Research, 34(1), 35-59. https://doi.org/10. 1007/s10693-008-0036-5

Elyasiani, E., \& Goldberg, L. G. (2004). Relationship lending: A survey of the literature. Journal of Economics and Business, 56(4), 315-330. https://doi.org/10.1016/j. jeconbus.2004.03.003

Erel, I., \& Liebersohn, J. (2020). Does FinTech substitute for banks? Evidence from the Paycheck Protection Program (No. w27659). National Bureau of Economic Research. https://doi.org/10.3386/w27659

Fairlie, R. (2020). The impact of COVID-19 on small business owners: Evidence from the first three months after widespread social-distancing restrictions. Journal of Economics \& Management Strategy, 29(4), 727-740. https://doi.org/10.1111/jems.12400

Fairlie, R., \& Fossen, F. M. (2021). The early impacts of the COVID-19 pandemic on business sales. Small Business Economics. https://doi.org/10.1007/ s11187-021-00479-4

Fairlie, R., Robb, A., \& Robinson, D. (2020). Black and White: Access to capital among minority-owned startups (No. w28154; p. w28154). National Bureau of Economic Research. https://doi.org/10.3386/w28154

Fang, H., \& Moro, A. (2011). Chapter 5 - Theories of statistical discrimination and affirmative action: A Survey**We thank Alberto Bisin, Jan Eeckhout, Yariv Fadlon, and Kevin Lang for providing comments on an initial draft of this chapter. We also thank our coauthors Glenn Loury and Peter Norman for providing many insights on statistical discrimination and affirmative action. In J. Benhabib, A. Bisin, \& M. O. Jackson (Eds.), Handbook of Social Economics (Vol. 1, pp. 133-200). North-Holland. https:// doi.org/10.1016/B978-0-444-53187-2.00005-X

FDIC. (2011). 2017 FDIC National Survey of Unbanked and Underbanked Households. 96.

Figlio, D. N., \& Genshlea, J. W. (1999). Bank consolidations and minority neighborhoods. Journal of Urban Economics, 45(3), 474-489. https://doi.org/10.1006/juec.1998. 2099

Flitter, E. (2020, July 15). Black business owners had a harder time getting federal aid, a study finds. The New York Times. https://www.nytimes.com/2020/07/15/business/ paycheck-protection-program-bias.html

Global Strategy Group. (2020). Federal stimulus survey findings. Prepared for Color of Change and Unidos US. https://theblackresponse.org/wp-content/uploads/2020/05/ COC-UnidosUS-Abbreviated-Deck-F05.13.20.pdf

Granja, J., Booth, C., Makridis, C., \& Sloan, M. (n.d.). Did the Paycheck Protection Program Hit the Target? 94.
Hegerty, S. W. (2016). Commercial bank locations and "banking deserts": A statistical analysis of Milwaukee and Buffalo. The Annals of Regional Science, 56(1), 253-271. https://doi.org/10.1007/s00168-015-0736-3

Hegerty, S. W. (2020). "Banking Deserts", bank branch losses, and neighborhood socioeconomic characteristics in the city of Chicago: A spatial and statistical analysis. The Professional Geographer, 72(2), 194-205. https://doi.org/ 10.1080/00330124.2019.1676801

Howell, S. T., Kuchler, T., \& Stroebel, J. (n.d.). Which lenders had the highest minority share among their Payment Protection Program (PPP) loans? 13.

Hubbard, R. G., \& Strain, M. (2020). Has the Paycheck Protection Program succeeded? (No. w28032; p. w28032). National Bureau of Economic Research. https://doi.org/ 10.3386/w28032

Humphries, J. E., Neilson, C. A., \& Ulyssea, G. (2020). Information frictions and access to the Paycheck Protection Program. Journal of Public Economics, 190, 104244. https://doi.org/10.1016/j.jpubeco.2020.104244

Ivashina, V., \& Scharfstein, D. (2010). Bank lending during the financial crisis of 2008. Journal of Financial Economics, 97(3), 319-338. https://doi.org/10.1016/j.jfineco.2009.12. 001

Jeschke, M. (2020, April 24). Ineligible PPP borrowers granted safe harbor period to return money by May 7 । Insights | Holland \& Knight. https://www.hklaw.com/en/ insights/publications/2020/04/not-yours-to-keep-ineli gible-ppp-borrowers-granted-safe-harbor-period

Kalogiannidis, S. (2020). Covid impact on small business. International Journal of Social Science and Economics Invention, 6(12), 387 to 391-387 391. https://doi.org/10. 23958/ijssei/vol06-i12/257

Kashian, R. D., Tao, R., \& Drago, R. (2018). Bank deserts in the USA and the Great Recession: Geography and demographics. Journal of Economic Studies, 45(4), 691-709. https://doi.org/10.1108/JES-05-2017-0121

Kelly, M. B., \& van Holm, E. J. (2021). Urbanization, community demographics, and the distribution of Paycheck Protection Program loans across counties (SSRN Scholarly Paper ID 3801348). Social Science Research Network. https://doi.org/10.2139/ssrn.3801348

Kurlyandchic, M. (2020, July 16). 785 Michigan restaurants got big PPP loans. 1 listed as Black-owned [Newspaper]. Detroit Free Press. https://www.freep.com/story/enter tainment/dining/mark-kurlyandchik/2020/07/16/michi gan-restaurants-payroll-protection-program-loans/53912 570021

Lederer, A., \& Oros, S. (2020). Lending Discrimination within the Paycheck Protection Program. 18. https://www.ncrc. org/lending-discrimination-within-the-paycheck-prote ction-program/

Leighton, P. (2020, July 16). Few Black-owned businesses get PPP loans | Local News | salemnews.com. https://www. salemnews.com/news/local_news/few-black-owned-busin esses-get-ppp-loans/article_764ff682-9ce9-529f-a94a9a38ecdda75d.html

Li, L., \& Strahan, P. E. (2020). Who supplies PPP loans (and does it matter)? Banks, relationships and the COVID crisis. SSRN Electronic Journal. https://doi.org/10.2139/ ssrn.3710929 
Li, M. (2020). Did the small business administration's COVID-19 assistance go to the hard hit firms and bring the desired relief? Journal of Economics and Business, 105969.https://doi.org/10.1016/j.jeconbus.2020.105969

Liu, H., \& Volker, D. (2020). The Paycheck Protection Program Liquidity Facility (PPPLF) -Liberty Street Economics. https://libertystreeteconomics.newyorkfed.org/2020/ 05/the-paycheck-protection-program-liquidity-facilityppplf.html

McKinsey. (2020). Building supportive ecosystems for Blackowned US businesses I McKinsey. https://www.mckinsey. com/industries/public-and-social-sector/our-insights/build ing-supportive-ecosystems-for-black-owned-us-businesses

Mijid, N., \& Bernasek, A. (2013). Decomposing racial and ethnic differences in small business lending: Evidence of discrimination. Review of Social Economy, 71(4), 443-473.

Mills, C. K. (n.d.). Double jeopardy: COVID-19's concentrated health and wealth effects in Black communities. Federal Reserve Bank of New York, 8.

Mitchell, K., \& Pearce, D. (2020). Availability of financing to small firms using the survey of small business finances.

Ong, P., Comandom, A., DiRago, N., \& Harper, L. (n.d.). COVID-19 impacts on minority businesses and systemic inequality. 31.

Parker, J. A., Souleles, N. S., Johnson, D. S., \& McClelland, R. (2013). Consumer spending and the economic stimulus payments of 2008. American Economic Review, 103(6), 2530-2553. https://doi.org/10.1257/aer.103.6.2530

Robb, A., \& Robinson, D. T. (2018). Testing for racial bias in business credit scores. Small Business Economics, 50(3), 429-443. https://doi.org/10.1007/s11187-017-9878-2

Shuai, X., Chmura, C., \& Stinchcomb, J. (2020). COVID-19, labor demand, and government responses: Evidence from job posting data. Business Economics. https://doi.org/10. 1057/s11369-020-00192-2
Smallbone, D., Ram, M., Deakins, D., \& Aldock, R. B. (2003). Access to finance by ethnic minority businesses in the UK. International Small Business Journal, 21(3), 291314. https://doi.org/10.1177/02662426030213003

Sobey, R. (2020, April 21). Harvard under fire for accepting more than $\$ 8 \mathrm{M}$ in coronavirus relief package. Boston Herald. https://www.bostonherald.com/2020/04/20/harva rd-under-fire-for-accepting-more-than- $8 \mathrm{~m}$-in-coronavirusrelief-package/

Tareque, I., Orozco, M., Oyer, P., \& Porras, J. (2021). U.S. Black-owned businesses: Pre-pandemic trends \& challenges (SSRN Scholarly Paper ID 3841149). Social Science Research Network. https://papers.ssrn.com/abstract= 3841149

Trevizo, P. (2020, June 8). When small businesses can't access PPP, local governments struggle to close the gap. San Antonio Express-News. https://www.expressnews.com/ news/local/article/When-small-businesses-can-t-accessPPP-local-15323521.php

Wheatley, W. P. (2010). Economic and regional determinants of the location of payday lenders and banking institutions in Mississippi: Reconsidering the role of race and other factors in firm location. The Review of Regional Studies, 40(1), 17.

Publisher's Note Springer Nature remains neutral with regard to jurisdictional claims in published maps and institutional affiliations. 